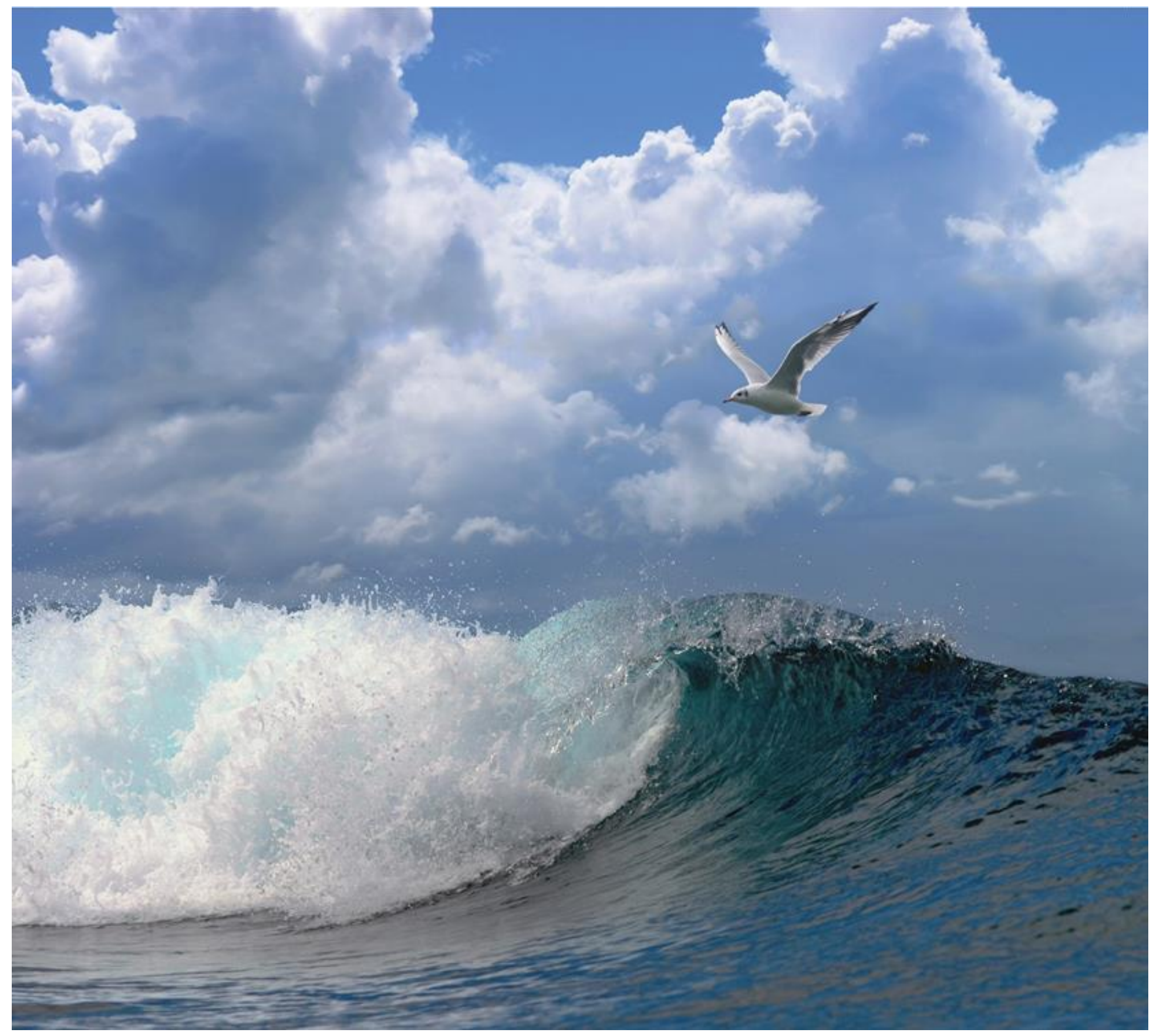

\title{
Platte oesters in offshorewindparken (POP)
}

Auteurs: Aad Smaal(1), Pauline Kamermans(1), Frank Kleissen(2), Luca van Duren(2) \& Tom van der Have(3)

1 Wageningen Marine Research, 2 Deltares, 3 Bureau Waardenburg
Wageningen University \& Research Rapport C035/17 


\section{Platte oesters in offshorewindparken (POP)}

Mogelijkheden voor de ontwikkeling van platte oester populaties in bestaande en geplande windmolenparken in het Nederlandse deel van de Noordzee

Auteur(s): $\quad$ Aad Smaal(1), Pauline Kamermans(1), Frank Kleissen(2), Luca van Duren(2) \& Tom van der Have(3)

Opdrachtgever: $\quad$ Ministerie van EZ, Directie Natuur \& Biodiversiteit

T.a.v.: de heer E. Knegtering

Postbus 20401

2500 EK Den Haag

BAS code BO-11018

Publicatiedatum: 5 april 2017

Dit onderzoek is uitgevoerd door Wageningen Marine Research i.s.m. Deltares en Bureau Waardenburg in opdracht van en gefinancierd door het Ministerie van Economische Zaken

1 Wageningen Marine Research, 2 Deltares, 3 Bureau Waardenburg

Yerseke, April 2017.

Wageningen Marine Research rapport C035/17 
Aad Smaal(1), Pauline Kamermans(1), Frank Kleissen(2), Luca van Duren(2) \& Tom van der Have(3), 2016. Platte oesters in offshorewindparken (POP)

Wageningen, Wageningen Marine Research rapport C035/17. 52 blz.

Dit rapport is gratis te downloaden van https://doi.org/10.18174/412950

Wageningen Marine Research, onderdeel van Stichting Wageningen Research KvK nr. 09098104,

IMARES BTW nr. NL 8113.83.696.B16

Code BIC/SWIFT address: RABONL2U

IBAN code: NL 73 RABO 0373599285

(C) 2016 Wageningen Marine Research Wageningen UR
De Directie van Wageningen Marine Research is niet aansprakelijk voor gevolgschade, noch voor schade welke voortvloeit uit toepassingen van de resultaten van werkzaamheden of andere gegevens verkregen van Wageningen Marine Research opdrachtgever vrijwaart Wageningen Marine Research van aanspraken van derden in verband met deze toepassing.

Dit rapport is vervaardigd op verzoek van de opdrachtgever hierboven aangegeven en is zijn eigendom. Niets uit dit rapport mag weergegeven en/of gepubliceerd worden, gefotokopieerd of op enige andere manier gebruikt worden zonder schriftelijke toestemming van de opdrachtgever. 



\section{Inhoud}

$\begin{array}{ll}\text { Samenvatting } & 5\end{array}$

$1 \quad$ Inleiding $\quad 6$

1.1 Doel $\quad 6$

$\begin{array}{lll}1.2 & \text { Achtergrond } & 6\end{array}$

$\begin{array}{llr}1.3 & \text { Habitateisen platte oester (Ostrea edulis) } & 8\end{array}$

$\begin{array}{lll}1.4 & \text { Probleemstelling } & 10\end{array}$

$\begin{array}{lll}1.5 & \text { Dankwoord } & 10\end{array}$

2 Kennisvraag $r 11$

3 Methoden $\quad 12$

$\begin{array}{lll}3.1 & \text { Habitateisen } & 12\end{array}$

$\begin{array}{lll}3.2 & \text { Bodembeweging en -schuifspanning } & 13\end{array}$

$\begin{array}{lll}3.3 & \text { Overige habitatkarakteristieken } & 16\end{array}$

$\begin{array}{ll}3.4 & \text { Larvenverspreiding } \\ 3.5 & 17\end{array}$

$\begin{array}{lll}3.5 & \text { Kritische massa } & 21\end{array}$

4 Resultaten $r 22$

$\begin{array}{lll}4.1 & \text { Habitateisen platte oester Noordzee } & 22\end{array}$

4.2 Modelsimulaties: bodemdynamiek en zwevend stof in de windparken 30

4.3 Geschiktheid windparklocaties voor platte oesters $\quad 35$

$\begin{array}{lll}4.4 & \text { Larventransport } & 37\end{array}$

$\begin{array}{lll}4.5 & \text { Kritische massa } & 41\end{array}$

$\begin{array}{lll}4.6 & \text { Integratie } & 43\end{array}$

$\begin{array}{lr}\text { 5. Conclusies } & 44\end{array}$

6. Aanbevelingen voor een pilot $\quad 45$

$\begin{array}{lr}\text { Kwaliteitsborging } & 47\end{array}$

$\begin{array}{lr}\text { Literatuur } & 48\end{array}$

$\begin{array}{lr}\text { Verantwoording } & 51\end{array}$ 


\section{Samenvatting}

Dit rapport gaat over de mogelijkheden voor de ontwikkeling van populaties platte oesters (Ostrea edulis) binnen bestaande en geplande windmolenparken in het Nederlandse deel van de Noordzee. In opdracht van het Ministerie van EZ is nagegaan welke eisen de platte oester stelt aan de omgeving, gericht op de habitatkarakteristieken van windparklocaties in de Noordzee. Daarbij is er vanuit gegaan dat er binnen de windparken geen sprake is van bodemberoerende activiteiten die nadelig zijn voor platte oesters.

Belangrijke randvoorwaarden voor de ontwikkeling van platte-oesterbanken in de windparken in het Nederlandse deel van de Noordzee zijn (i) grootschalige en kleinschalige bodemdynamiek, (ii) sedimentsamenstelling, (iii) zwevendstofgehalte, en (iv) de mogelijkheid voor succesvolle rekrutering. Dit laatste hangt af van de omvang van de ouderpopulatie en de aanvoer van larven door middel van de waterbeweging.

Andere factoren zoals voedselaanbod en zuurstofgehalte zijn ook belangrijk maar die zijn in de betreffende gebieden in de Noordzee niet beperkend; predatie en competitie zijn eveneens van belang maar daarvan is niet aan te geven in hoeverre dit beperkingen oplevert voor de ontwikkeling van platte-oesterbanken in de windparken en in hoeverre de windparken hierin van elkaar verschillen. De relatieve geschiktheid van de windparken voor de platte oester wordt volgens onze analyse bepaald door de kleinschalige bodemdynamiek, uitgedrukt als bodemschuifspanning, de sedimentsamenstelling, het zwevendstofgehalte en de kans op rekrutering. Grootschalige bodemdynamiek in de vorm van zandgolven, is beperkend in een deel van het Borssele-gebied - maar niet overal -, in de andere parken speelt dit geen rol. Er is verder ook gekeken naar gegevens over het voorkomen van oesterbanken in het verleden, als een kwalitatieve ijking van de geschiktheid van gebieden.

De conclusie is dat Zee-energie in combinatie met Buitengaats relatief de meest geschikte locaties zijn voor de ontwikkeling van oesterbanken, gevolgd door Borssele en Luchterduinen. In de ondiepere kustlocaties zijn er ook mogelijkheden voor oesterbanken maar daar is de bodem net wat minder stabiel. Op basis van de waterbeweging en de duur van de larvale fase is een inschatting gemaakt van de afstand waarover larven verspreid worden. Op basis van die analyse komen Zeeenergie en Buitengaats, gevolgd door Borssele naar voren als meest geschikte locaties voor broedval. Andere locaties langs de Hollandse kust zijn op dit moment minder goed in staat zelfvoorzienend te worden qua larven, al zijn sommige van deze locaties wel in staat om andere windparken of de geulen van de Waddenzee van larven te voorzien.

Gezien de aannames en onzekerheden is empirische toetsing van de conclusies via pilotexperimenten een noodzakelijke stap in de verdere ontwikkeling van platte-oesterbanken in de Noordzee windparken. Aangezien Luchterduinen sinds 2015 in gebruik is als park, en relatief goed bereikbaar, is deze kansrijke locatie direct inzetbaar voor pilots. 


\section{Inleiding}

\subsection{Doel}

Het doel van het project is te identificeren waar er mogelijkheden zijn voor de ontwikkeling van populaties platte oester (Ostrea edulis) binnen bestaande en geplande windmolenparken in het Nederlandse deel van de Noordzee en aan te geven wat er nodig is om tot pilotstudies te komen voor het ontwikkelen van deze populaties.

\subsection{Achtergrond}

Het kabinet heeft in september 2014 drie gebieden aangewezen waar de komende jaren windparken op zee kunnen worden ontwikkeld, te weten Borssele, Noord-Holland en ZuidHolland (Figuur 1.1). In de Noordzee Gebiedsagenda 2050 spreken de ministeries van Economische Zaken en Infrastructuur en Milieu de ambitie uit te komen tot gecombineerd gebruik van ruimte op zee. Bij het ministerie van Economische zaken leeft de specifieke vraag of er binnen de recentelijk aangewezen offshorewindparken mogelijkheden zijn voor de ontwikkeling van platte-oesterbanken. De mogelijkheid voor de ontwikkeling van platteoesterbanken doet zich bij uitstek voor in de windparken omdat aldaar bodem-beroerende activiteiten zijn uitgesloten, en dit wordt gezien als een belangrijke randvoorwaarde voor het herstel van de historisch op grote schaal aanwezige platte-oesterbanken in de Noordzee (Gercken \& Schmidt, 2014; Smaal et al, 2015).

Aanleiding voor het onderzoek naar de mogelijkheden voor de ontwikkeling van platte oesters in windparken op zee zijn de in de kavelbesluiten voor nieuwe windparken opgenomen voorschriften met betrekking tot natuurinclusief ontwerpen. Het kader is enerzijds het rijksbeleid over "bouwen met Noordzeenatuur", dat versterking beoogt van behoud en duurzaam gebruik van soorten en habitats die van nature in de Nederlandse Noordzee voorkomen en betreft anderzijds diverse voornemens voor herintroductie van platte-oesterbanken in de Noordzee. De achtergrond hiervan is dat de Noordzee door verschillende menselijke activiteiten veranderd is (Houziaux et al, 2011), mede vanwege het verlies van verschillende uitgestrekte banken van platte oesters die in de $19^{\mathrm{e}}$ eeuw grootschalig aanwezig waren in de Noordzee (Olsen, 1883; Smaal et al., 2015). Gezien de plannen voor uitbreiding van het areaal aan windparken is de vraag in hoeverre dit mogelijkheden biedt voor de ontwikkeling van de populatie platte oesters in die gebieden.

In figuur 1.1 en tabel 1.1 zijn de locaties aangegeven die in deze studie aan de orde komen. Dit betreft de reeds in gebruik zijnde locaties Owez, Amalia en Luchterduinen, aangevuld met de locaties die in aanbouw zijn (Buitengaats en Zee-energie), die onlangs zijn vergund (Borssele) en waar de besluitvorming in voorbereiding is (Noord-Holland en Zuid-Holland). De locaties voor de langere termijn (zie tabel 2.1) zijn in deze studie niet meegenomen. 


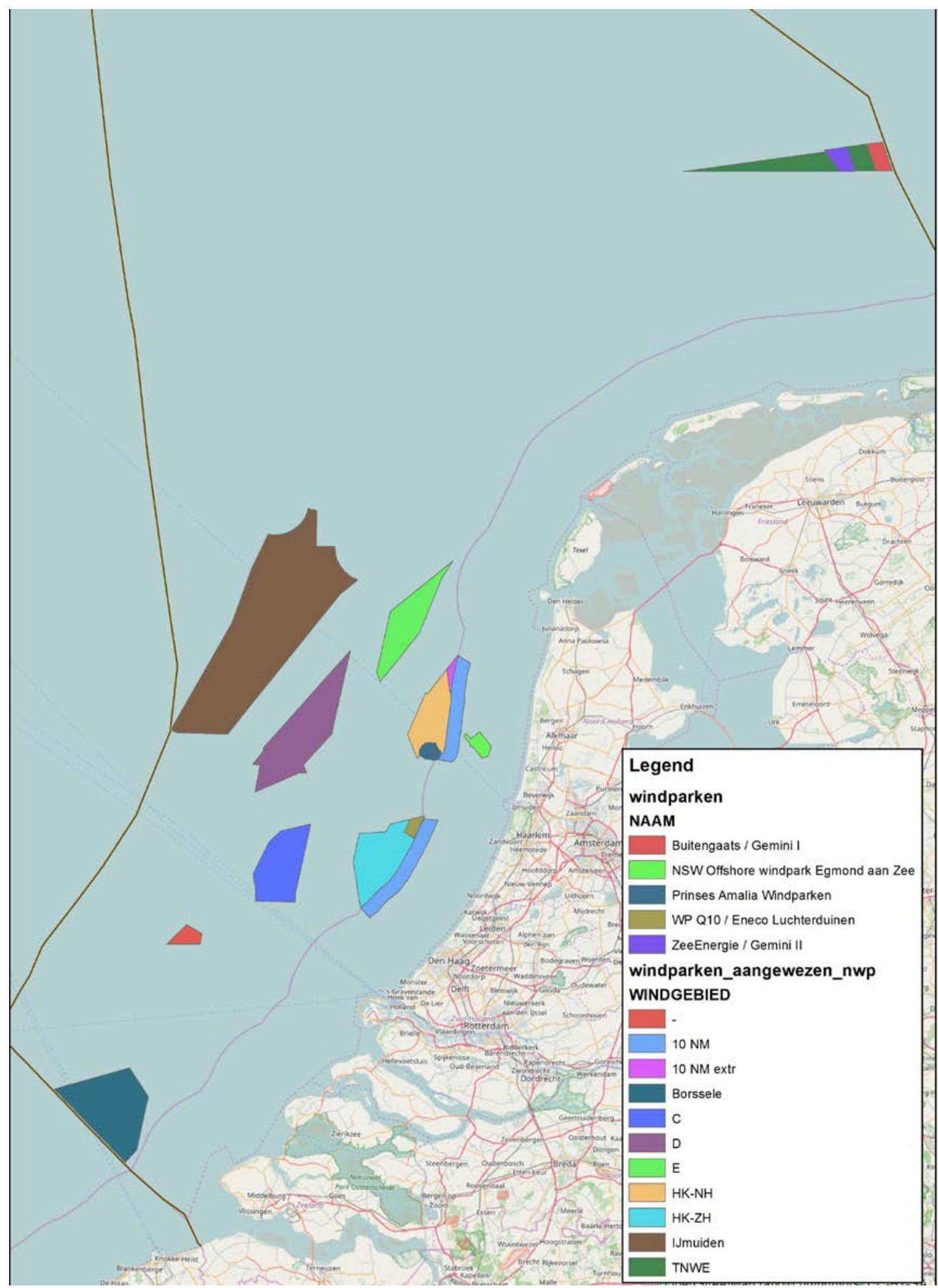

Figuur 1.1. Overzicht van de ligging van de bestaande en geplande windparklocaties in het Nederlandse deel van de Noordzee. Deze studie is gericht op de in tabel 1.1. aangegeven locaties. 
Tabel 1.1 Windparklocaties in het NCP die in deze studie worden onderzocht.

\begin{tabular}{|r|l|r|l|}
\hline nr & naam & $\begin{array}{c}\text { oppervlak } \\
(\mathrm{km} 2)\end{array}$ & $\begin{array}{l}\text { diepte } \\
(\mathrm{m})\end{array}$ \\
\hline 1 & Borssele totaal & 34501 & $20-40$ \\
\hline 2 & Buitengaats & 3428 & $28-36$ \\
\hline 3 & OWEZ & 2612 & $15-21$ \\
\hline 4 & Holl. Kust N & 17368 & $20-27$ \\
\hline 5 & Holl. Kust Z & 23593 & $20-27$ \\
\hline 6 & Luchterduinen & 1590 & $20-27$ \\
\hline 7 & Pr. Amalia & 2167 & $20-27$ \\
\hline 8 & Zee-energie & 3337 & $33-40$ \\
\hline
\end{tabular}

\subsection{Habitateisen platte oester (Ostrea edulis)}

Platte oesters leven op de bodem en kunnen biogene riffen vormen, en worden daarom ook wel bio bouwers genoemd (Smaal et al, 2015). Met hun kieuwen nemen ze zuurstof op en filtreren ze algen uit het water als voedsel. Bij een te hoog zwevendstofgehalte raken de kieuwen verstopt en wordt er minder voedsel opgenomen. Oesters beginnen hun leven als mannetje en worden later in hun leven vrouwtje, daarna kan er geslachtswisseling optreden. Na de bevruchting blijven de larven eerst in de mantel van de moederoester. Vervolgens zweven ze ongeveer 7 -14 dagen in het water voordat ze zich op de bodem vestigen (Smyth et al, 2016). Deze vestiging is eenmalig. Predatie op vooral jonge oesters vindt plaats door krabben, zeesterren en roofslakken zoals oesterboorders.

Platte oesters komen voor binnen bepaalde grenzen aan abiotische factoren (bodemdynamiek, waterdiepte, saliniteit, watertemperatuur, zuurstofgehalte van het water, stroomsnelheid - ook i.v.m. retentie larven en broedval, zwevendstofgehalte van het water, substraat - ook geschikt voor broedval) en biotische factoren (voldoende fytoplankton, weinig predatie, weinig uitval door ziektes, populatie groot genoeg voor voldoende broedval om rif in stand te houden en uit te breiden). Op basis van de habitateisen van de platte oester, en de habitatkarakteristieken van de huidige en geplande windparklocaties in het Nederlandse deel van de Noordzee, is in dit rapport nagegaan wat de mogelijkheden zijn voor de ontwikkeling van platte-oesterpopulaties in die gebieden.

\subsubsection{Bodemdynamiek}

Bij potentiële locaties voor herstelprojecten is het belangrijk dat deze zodanig gekozen worden dat het habitat er niet alleen geschikt is voor populaties van volwassen dieren, maar ook voor het vestigen van larven. Rifvormende schelpdieren zoals de platte oester, zijn zgn. ecosystem engineers (biobouwers). Dat wil zeggen dat deze soorten hun fysische omgeving dusdanig beïnvloeden dat het habitat voor deze soort en andere soorten verbetert. Platte oesters hebben enig hard substraat nodig voor initiële vestiging, maar kunnen vervolgens een bestaand rif uitbouwen over zacht substraat heen. Voor een rif is het belangrijk dat de bodem relatief stabiel is. Gunstige locaties worden enerzijds bepaald door de lokale bodemsamenstelling, maar ook door de mobiliteit van de bodem. De riffen werken stabiliserend op de bodem, maar zijn niet 
bestand tegen grote (metershoge) zandgolven die op veel plaatsen op het NCP door het gebied "lopen". Met behulp van modellen is ingeschat wat de kleinschalige en grootschalige bodemdynamiek is voor elk van de windparklocaties, op basis van simulaties van de bodemschuifspanning en de bodemligging.

\subsubsection{Overige habitatkarakteristieken}

Voor de platte oester is een zekere stabiliteit van de bodem niet de enige relevante habitateis. Een goed leefgebied dient voldoende zuurstof en voedsel (fytoplankton) te hebben, de juiste saliniteit- en watertemperatuurrange, niet teveel predatoren en voldoende geschikt substraat voor vestiging. Daarbij kan competitie om voedsel en ruimte optreden met andere bodemdiersoorten. Nagegaan is in $\mathrm{H} 4$ wat er over deze variabelen bekend is in de zoekgebieden.

\subsubsection{Larvenverspreiding}

Bij platte oesters worden de eitjes binnen de schelp van dieren die op dat moment vrouwtjes zijn bevrucht en na enige tijd vrijgelaten. Ze zweven dan afhankelijk van temperatuur en voedsel ca 10 dagen vrij rond als plankton in de waterkolom, worden verspreid door de stroming en vestigen zich daarna op geschikt substraat. Larven die op het punt staan zich te gaan vestigen worden "competente" larven genoemd. Voor een levensvatbare populatie is er voldoende aanvoer van competente larven nodig. Met behulp van een verspreidingsmodel dat is gebaseerd op een gevalideerd stromingsmodel van de Noordzee wordt in $\mathrm{H} 4$ in beeld gebracht hoe larven vanuit verschillende bronnen (hier: vanuit verschillende windparken) zich verspreiden over de Noordzee. Op basis van deze modelresultaten is geschat wat de reikwijdte is van de larven die in een bepaald windpark worden geproduceerd en in hoeverre er retentie is van larven in een bepaald gebied. Enerzijds is een hoge mate van retentie voor een herstelproject belangrijk. Als na 10 dagen alle larven uit het windpark zijn verdwenen zal deze locatie nooit zelfvoorzienend kunnen worden m.b.t. larvenaanvoer. Anderzijds is een bepaalde mate van dispersie wel wenselijk als een herstelproject in de toekomst ook als bronpopulatie moet dienen voor ander geschikt habitat.

\subsubsection{Kritische massa platte oesters}

Een cruciale vraag bij de ontwikkeling van oesterpopulaties is welke omvang minimaal noodzakelijk is om voldoende rekrutering te verkrijgen voor een levensvatbare populatie. De minimale omvang wordt bepaald door de leeftijdsopbouw, de dichtheid, de hoeveelheid geproduceerde larven en de waterbeweging. Daarbij geldt dat de oesters hun leven beginnen als mannetje en pas na 3 a 4 jaar de metamorfose tot vrouwtje ondergaan (en daarna afwisselend van het mannelijk of vrouwelijk geslacht kunnen zijn). De populatie moet dus niet alleen een minimale omvang hebben maar ook de juiste opbouw in jaarklassen. Schattingen over de kritische massa lopen in de literatuur nogal uiteen. Volgens Berghahn \& Ruth (2005) is er een zeer groot oesterbestand nodig in de Noordzee - orde grootte vele tientallen miljoenen oesters voor succesvolle rekrutering in de Noordzee en de Waddenzee. Dit is gekoppeld aan de openheid van deze systemen en de herkomst van de larven, die volgens deze auteurs allereerst vanuit het Kanaal komen. Smyth et al (2016) laten echter zien dat herstel van de platte-oesterpopulatie na overexploitatie mogelijk was in Strangford Lough op basis van een beperkte kritische massa 
platte oesters. Op basis van modelberekeningen van de verspreiding van oesterlarven gegenereerd in de windparken in de Noordzee, is geschat hoe groot de ouderpopulaties zouden moeten zijn om voldoende larven over te houden voor nieuwe rekrutering.

\subsection{Probleemstelling}

De vraagstelling zoals geformuleerd door de opdrachtgever betreft vooronderzoek naar aanwezige habitatfactoren voor platte oesters op specifieke locaties in de Noordzee. Het onderzoek is gericht op locaties binnen bestaande en geplande windmolenparken in de EEZ van de Nederlandse Noordzee op een schaalniveau dat relevant is voor de ontwikkeling van platteoesterriffen, waar eventuele pilot-experimenten kunnen worden uitgevoerd. Uit de resultaten van voorliggend onderzoek moet duidelijk worden welke locaties de beste mogelijkhden bieden voor experimentele (her)introductie van platte oesters.

\subsection{Dankwoord}

De auteurs bedanken dr E. Knegtering van het ministerie van Economische Zaken voor het verlenen van de opdracht en waardevol commentaar op de conceptversie, en Dr J. Wijsman (WMR) voor de review van het rapport. 


\section{Kennisvraag}

De centrale kennisvraag binnen deze studie betreft:

Op welke offshiorewindparklocaties, en eventuele delen daarbinnen, zijn geschikte

habitatfactoren aanwezig voor eventuele (her)introductie van platte oesters, en waar zijn deze gelegen?

De studie richt zich op gebieden binnen de windparklocaties in het Nederlandse deel van de Noordzee (NCP, Figuur 1.1). In tabel 2.1 is aangegeven op welke termijn de windparklocaties worden gerealiseerd. De realisatietermijn is de basis voor prioritering van de locaties in onderhavige studie. Dat wil zeggen dat het onderzoek is gericht op de locaties met 2 en 3 sterren.

Tabel 2.1. Overzicht windparklocaties in het NCP, termijninschatting en de in voorliggend onderzoek gehanteerde prioriteit voor een nadere uitwerking van de potentiële platte-oesterhabitats $(* * *$ en $* *)$; (Ministerie van Infrastructuur en Milieu \& van Economische Zaken, 2014, 2016)

\begin{tabular}{|c|c|c|c|}
\hline Code & Locatie & realisatiestadium & Prioriteit \\
\hline $\mathrm{C}$ & OWEZ (Egmond aan Zee), & In bedrijf & $* *$ \\
\hline $\mathrm{C}$ & Prinses Amalia & In bedrijf & $* *$ \\
\hline C & Luchterduinen & In bedrijf & $* *$ \\
\hline A & Ijmuiden ver & besluitvorming op lange teremijn & $*$ \\
\hline \multirow[t]{6}{*}{ B } & Windenergiegebied "Borssele" & & \\
\hline & kavel I & exploitant bekend & $* * *$ \\
\hline & kavel II & exploitant bekend & $* * *$ \\
\hline & kavel III & exploitant bekend & $* * *$ \\
\hline & kavel IV & exploitant bekend & $* * *$ \\
\hline & kavel V Innovatiekavel) & kavelbesluit & $* *$ \\
\hline \multirow[t]{12}{*}{ C } & Windenergie "Hollandse kust" & & $* *$ \\
\hline & Zuid-Holland kavel I & ontwerp kavelbesluit, tender half 2017 open & ** \\
\hline & Zuid-Holland kavel I & ontwerp kavelbesluit, tender half 2017 open & $* *$ \\
\hline & Zuid-Holland kavel I & tender ca 2018 open & $* *$ \\
\hline & Zuid-Holland kavel I & tender ca 2018 open & $* *$ \\
\hline & Noord-Holland kavel I & tender ca 2019 open & ** \\
\hline & Noord-Holland kavel I & tender ca 2019 open & ** \\
\hline & Zuid (Kavel III + IV) & besluitvorming in voorbereiding & $* *$ \\
\hline & resterende locatie (1) & besluitvorming op langere termijn & $*$ \\
\hline & resterende locatie (2) & besluitvorming op langere termijn & $*$ \\
\hline & resterende locatie ( 3 ) & besluitvorming op langere termijn & $*$ \\
\hline & resterende locatie (4) & vooralsnog buiten beschouwing & \\
\hline \multirow[t]{5}{*}{ D } & $\begin{array}{l}\text { Windenergiegebied "Ten noorden van } \\
\text { de Waddeneilanden" }\end{array}$ & & \\
\hline & Gemini: Buitengaats & in aanbouw & $* *$ \\
\hline & Gemini: Zee-energie & in aanbouw & $* *$ \\
\hline & resterende locatie (1) & besluitvorming op langere termijn & $*$ \\
\hline & resterende locatie (2) & besluitvorming op langere termijn & * \\
\hline
\end{tabular}




\section{Methoden}

Deze deskstudie bestaat uit literatuur- en bronnenonderzoek aangevuld met modelsimulaties. Voor het literatuur- en bronnenonderzoek is gebruik gemaakt van open literatuur, databases en diverse recente rapportages, met name Capelle, 2008, Smaal et al, 2015, Kamermans et al, 2015, van der Have \& van der Zee, 2016, Sas et al, 2016 en van Duren et al 2016. Verder is gebruik gemaakt van informatie over historische en recente verspreiding van de oesters in en nabij de Noordzee. Uit deze veldgegevens kan worden afgeleid welke locaties kennelijk kansrijk zijn voor oesters.

\subsection{Habitateisen}

De eisen die de oesters stellen aan hun omgeving zijn geanalyseerd in termen van grenswaarden van abiotische factoren en biotische factoren. Informatie hierover is verkregen uit de literatuur (o.a. via de WUR-bibliotheek, Scopus, Google scholar, en andere bronnen), via bestaande contacten van de auteurs en op basis van informatie over het voorkomen van de platte oesters.

Vier life-history-processen bepalen in belangrijke mate de voorwaarden voor een duurzame ontwikkeling van een platte-oesterbank: Overleving, Groei, Reproductie en Rekrutering (OGRR). Met reproductie wordt bedoeld het vermogen om nageslacht te produceren; de term rekrutering duidt op de succesvolle vestiging van de larven op een bepaalde locatie.

Een reeks van abiotische en biotische factoren is van invloed op deze vier processen, samengevat in Tabel 3.1.1. Overleving is afhankelijk van omgevingsfactoren als grootschalige en kleinschalige bodemdynamiek, zuurstof- en zoutgehalte en predatie. Groei wordt vooral bepaald door fytoplankton- en zwevendstofgehalte. Reproductie vereist de juiste samenstelling van het ouderbestand en voor paaien is de watertemperatuur belangrijk. Rekrutering is afhankelijk van de watertemperatuur, de hoeveelheid larven in een bepaald gebied en de aanwezigheid van geschikt substraat voor vestiging. Rekrutering wordt bepaald door de omvang van het ouderbestand dat de larven produceert en tevens dient als substraat, en de waterbeweging die de retentie van larven in een gebied bepaalt (zie ook: Vera et al, 2016; Smyth et al, 2016).

\section{Leeswijzer}

Het rapport gaat in op habitateisen van de oester enerzijds, en op de vraag wat de waarden zijn van de verschillende omgevingsfactoren in de windmolenparken anderzijds. Deze factoren zijn weergegeven in tabel 3.1.1. en voor zover mogelijk nader ingevuld in tabel 4.1.1. Voor bodemschuifspanning, bodemligging en zwevendstofgehalte is gebruik gemaakt van modelberekeningen, die nader worden toegelicht in $\mathrm{H}$ 3.2. Voor de overige factoren is uitgegaan van literatuurgegevens. Voor de verspreiding van larven en de schatting van de kritische massa is eveneens van modelberekeningen gebruik gemaakt, die in $\mathrm{H} 3.4$ worden toegelicht. Ook in $\mathrm{H} 4$ wordt apart ingegaan op de modellen en de uitkomsten van de berekeningen. 
Tabel 3.1.1. Omgevingsfactoren die van belang zijn voor de verschillende life-history-processen

\begin{tabular}{|l|l|l|l|l|}
\hline & overleving & groei & reproductie & rekrutering \\
\hline bodemschuifspanning & $\mathrm{x}$ & & & \\
\hline bodembeweging & $\mathrm{x}$ & & & \\
\hline zwevend stof conc & & $\mathrm{x}$ & & \\
\hline watertemperatuur & & & $\mathrm{x}$ & \\
\hline sediment samenstelling / substraat & & & & $\mathrm{x}$ \\
\hline waterdiepte & $\mathrm{x}$ & & & \\
\hline zoutgehalte & $\mathrm{x}$ & & & \\
\hline voedsel conc. & & $\mathrm{x}$ & & \\
\hline zuurstofgehalte & $\mathrm{x}$ & & & \\
\hline stroomsnelheid & & & & $\mathrm{x}$ \\
\hline predatie & $\mathrm{x}$ & & & \\
\hline competitie & & $\mathrm{x}$ & & \\
\hline samenstelling ouderbestand & & & $\mathrm{x}$ & \\
\hline omvang ouderbestand & & & & $\mathrm{x}$ \\
\hline
\end{tabular}

\subsection{Bodembeweging en -schuifspanning}

Bodemdynamiek kan op verschillende schaalniveaus worden beschreven. Daarom wordt onderscheid gemaakt in bodembeweging (geomorfologie), dit is de bodemdynamiek op grotere schaal, en bodemschuifspanning, dit is de maat voor lokale dynamiek van de bodem.

\section{Bodembeweging}

De bodemligging en -beweging in de Noordzee is weergegeven in figuur 3.2.1, ontleend aan de Noordzeeatlas (Icona, 1992). Daarin staat de volgende beschrijving van de bodemligging. “De zeebodem voor de Nederlandse kust heeft verschillende vormen, zoals zandbanken, zandgolven en eb-delta's. In grote lijnen kunnen we onderscheid maken tussen de vlakke zeebodem en de onderwateroever. De vlakke zeebodem heeft een algemene helling van maximaal 1:1000. Het zuidelijke deel wordt gekenmerkt door zandgolven die in hoogte afnemen: van meer dan 6 meter in het zuiden tot 2 meter ter hoogte van Den Helder. Verder noordwaarts komen vrijwel geen zandgolven voor, met uitzondering van een gebied ter hoogte van Texel en Vlieland. De lengte van de banken varieert van enkele tot tientallen kilometers. Ze zijn één tot enkele kilometers breed. De banken in het zuidelijke complex (de Zeeland Banken) liggen dieper (2030m - NAP) dan die in het noordelijke complex (14-20m -NAP). De zuidelijke banken hebben een hoogte van 4 tot 20 meter, de noordelijke zijn 3 tot 6 meter hoog. De vlakke zeebodem gaat kustwaarts over in de sterker hellende onderwateroever. De overgang ligt in het algemeen op ongeveer 20m - NAP (15m - NAP bij het centrale deel van de Hollandse kust). Bij de zeegaten in het Deltagebied en het Waddengebied wordt de onderwateroever gedomineerd door buitendelta's met bijbehorende geulen en platen. De helling van de onderwateroever neemt bij de Hollandse kust en de centrale delen van de Waddeneilanden kustwaarts toe."

Voor de windparken geldt dat met name Borssele deels een relatief dynamische bodem heeft. Daarom zijn de zandgolven nader geanalyseerd voor dit gebied ( H 4.2.2), op basis van 14 
bodemsurveys die zijn uitgevoerd tussen 1988 en 2014. De gegevens zijn verzameld door de Nederlandse Koninklijke Marine en door Deltares opgewerkt voor het Windpark Borssele. Voor details over de methode zie Riezebos et al (2014). De bodemligging in de andere parken is meer stabiel (Fig 3.2.1).

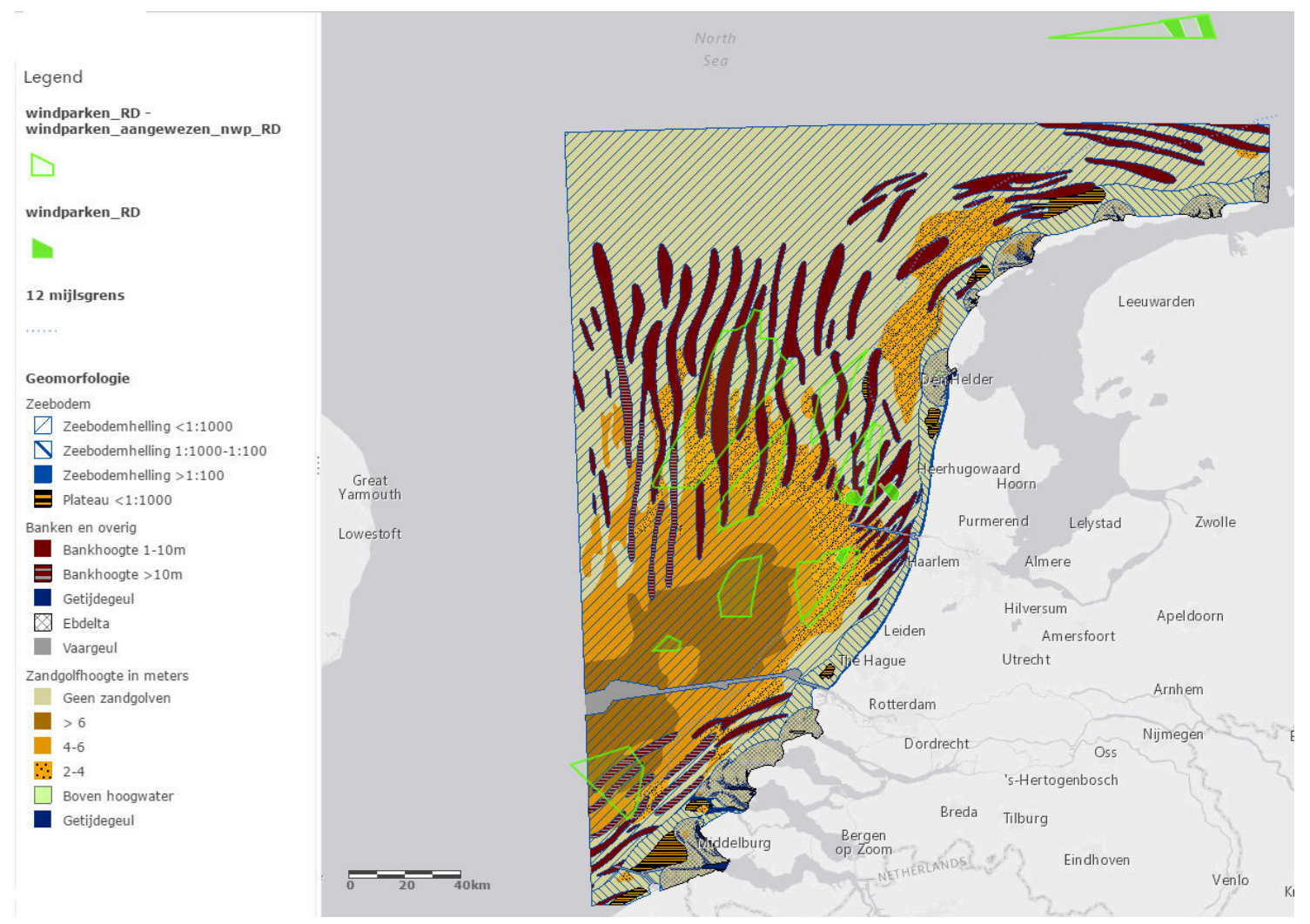

Figuur 3.2.1 Bodemligging/beweging (uit: Noordzeeatlas, Icona, 1992) en windparklocaties in het Nederlands deel van de Noordzee.

\section{Bodemschuifspanning en slibmodel}

Bodemschuifspanning is de kracht die bewegend water op de bodem uitoefent. Het is het resultaat van zowel stroming als van golven. In diep water dringen golven niet door tot op de bodem, in ondiep water is de kracht van golfwerking meestal dominant. De bodemschuifspanning bepaalt of deeltjes (bv. slib, zand of oesterlarven) opgewerveld worden of bezinken.

Er zijn geen directe meetgegevens van bodemschuifspanning beschikbaar. Dit soort gegevens is alleen te verkrijgen uit modellen. Om een indruk te krijgen van de gemiddelde en de maximale bodemschuifspanning in de Noordzee is gebruik gemaakt van gegevens uit de slibmodellering van de MER-Zandwinning (in voorbereiding). Rijkswaterstaat en Stichting LaMER laten gezamenlijk een Milieu Effect Rapportage opstellen voor de voorgenomen zandwinactiviteiten 2018-2027. Deltares en Wageningen Marine Research hebben een voorstudie uitgevoerd, waarin de effecten van zandwinning op de slibhuishouding inzichtelijk worden gemaakt. Onderdeel van deze studie is een gedetailleerd slibmodel, gebaseerd op een gevalideerd hydrodynamisch model van de waterbeweging in de zuidelijke Noordzee (Fig 3.2.2). Dit is een "state of the art" - model, 
gebaseerd op eerdere modelstudies en momenteel het beste dat direct beschikbaar is. Voor stroming en slib is een serie validatiedata gebruikt over de jaren 2003 - 2011. Met deze meerjarige dataserie is een validatie van het model uitgevoerd en is tevens inzicht te krijgen in jaar-op-jaar-variabiliteit.

Het hydrodynamische model is tevens gebruikt als input voor het modelleren van de verspreiding van de oesterlarven zoals beschreven in hoofdstuk 4.4
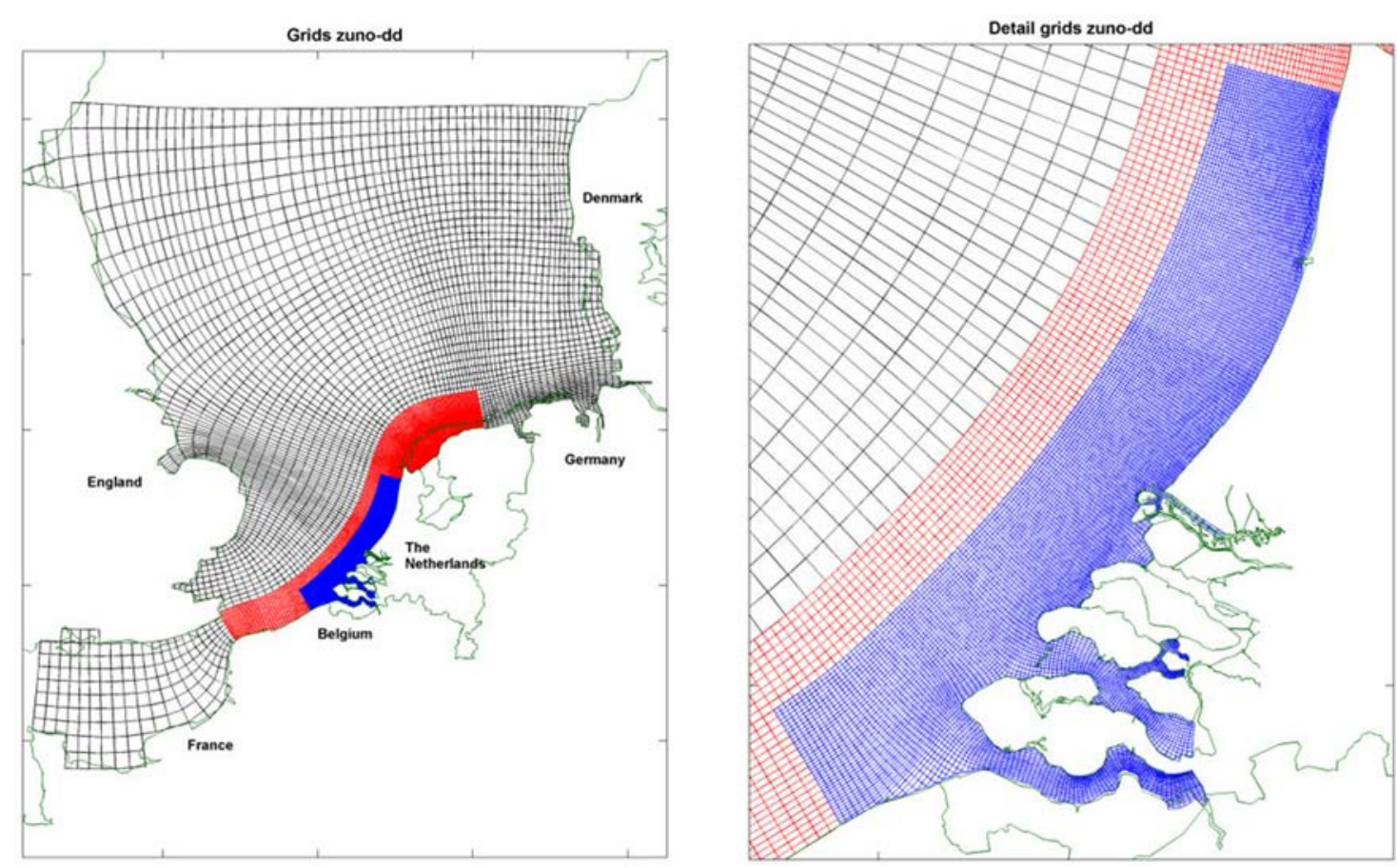

Figuur 3.2.2: Rooster van het gebruikte grid van het hydrodynamische model, weergegeven op 2 schaalnivo's.

Naast modellering van de stroming is voor de slibmodellering ook gebruik gemaakt van een golfmodel van de TU Delft (SWAN, F. Kleissen mond med). Uit de gecombineerde resultaten van het hydrodynamisch model en het golfmodel is een schatting gemaakt van de bodemschuifspanning. Op basis van deze gegevens is een inschatting gemaakt van de opwerveling van sediment en daarmee van de sedimentconcentratie in de verschillende lagen van het model. In de basis is de modelaanpak dezelfde als gehanteerd in de vorige MER (Keetels et al., 2012) en MOS-II (Cronin et al., 2013). Op een aantal punten zijn er voor onderhavige studie aanpassingen doorgevoerd:

- Het model is geactualiseerd met de meest recente parameter-instellingen zoals toegepast in de MOS II en loswalstudies. Deze hebben na de vorige MER zandwinning (Keetels et al, 2012) plaatsgevonden en de parameter-instellingen zijn naar aanleiding van meer en nieuwere meetgegevens van de slibconcentratie gevalideerd. Bovendien is in de loswalstudie het effect van de havenaanslibbing enerzijds en de verspreiding van onderhoudsbaggerspecie anderzijds aan het model toegevoegd.

- Het model is geconverteerd naar een nieuw rooster en een nieuwe bodem.

- Het golfmodel is opnieuw gedraaid voor de periode 2003 - 2011 voor het nieuwe rooster en de nieuwe bodem. Dit is gebeurd met dezelfde golfassimilatietechniek als toegepast voor de vorige MER zandwinning en de MER Maasvlakte-2. 
- Ter validatie is het model met het nieuwe rooster en bodem en de nieuwe golfmodellering gedraaid voor de periode 2003 - 2011. Er is hierbij gebruik gemaakt van de scripts voor naverwerking en validatie zoals ontwikkeld in het project MOS II (Cronin et al.,2013) en de vorige MER zandwinning (Keetels et al., 2012).

Meer details over dit model kunnen gevonden worden in het validatierapport voor de MERZandwinning (in voorbereiding).

\subsection{Overige habitatkarakteristieken}

Naast bodem- en slibdynamiek zijn (literatuur)gegevens verzameld over andere voor platte oesters relevante variabelen, zoals sedimentsamenstelling, watertemperatuur, fytoplankton en zuurstofgehalte en saliniteit (zie ook 3.1). Die werden ontleend aan o.a. de Noordzee-atlas (Icona, 1992) en andere databases. Ook is nagegaan wat er bekend is van fauna op de windparklocaties inclusief mogelijke predatoren, onder meer op basis van gegevens uit onderzoek naar de begroeiing van wrakken in de windparklocaties (Lengkeek et al, 2013). Verder is gebruik gemaakt van historische kaarten over de oesterverspreiding en de habitatkarakteristieken van die gebieden. In het huidige Nederlandse deel van de Noordzee komt de platte oester alleen voor in de Voordelta en incidenteel op harde substraten. De veldkennis over de relevante abiotische en biotische factoren is daarom voornamelijk afkomstig uit andere delen van het verspreidingsgebied. Aanvullende informatie is beschikbaar m.b.t. de historische verspreiding van platte oesters in de Noordzee (e.g., Olsen, 1883, Gercken \& Schmidt, 2014; Smaal et al., 2015). De historische verspreiding is daarom als een extra "habitatfactor" gebruikt om de geschiktheid van gebieden in de Noordzee voor platte oesters te evalueren. In dit verband is onderstaand citaat interessant, ontleend aan het Dagblad van Zuid-Holland en s-Gravenhage, 29 februari 1856.

In den lititsten tijol heeft men ook voor Selievenin an eene asterbitnk ontdekt. Door de vissehers worlen allitar vin tijd tot tij.l ocsters nangebragt: manr dewijl zij uit de diepte ojpeviocht worden, zijn zij te zout van smatik. "Wij willen en kunnen echter niet beslissen, in hoc ver zij geschikt zijn om wet andire spijzen te worden tocherejil. Dais rele koks de kinst vertaan, om de mosselen als oesters. ende kr.ubluen als kreeften toe to irereiden, zullen zij \%ckor vatn de Silurieningsthe oesters ook wol partij weten to trekken."

De geselecteerde windparklocaties zijn beoordeeld op basis van de kaarten die voor de meest relevante habitateisen zijn samengesteld. De resulterende waarden zijn geëvalueerd op basis van de tolerantiegrenzen van platte oesters uit de literatuur. 


\subsection{Larvenverspreiding}

\subsubsection{Algemeen}

Om een inschatting te krijgen van mogelijke verspreiding van oesterlarven vanuit diverse locaties en de kans op rekrutering, is gebruik gemaakt van een deeltjesverspreidingsmodel (waarbij de deeltjesmodel staan voor de larven) dat is aangedreven door waterbeweging van het Delft3D-FLOW-model. Delft3D-FLOW is een onderdeel van de zogeheten Delft3D-suite van modellen en genereert de waterbeweging dat het transport van stoffen aandrijft. Andere Delft3D-modules, zoals voor waterkwaliteit, primaire en secundaire productie en deeltjestransport, zijn hier direct aan gekoppeld. De 3-dimensionele waterbeweging is afkomstig van het zogenaamde ZUNO-DD-model dat voor Rijkswaterstaat is opgezet in het kader van de MER zandwinning. Het ZUNO-DD-model is een hydrodynamisch model van de zuidelijke Noordzee (zie fig 3.4.1.1.). Aangezien dit model vooral gebruikt wordt om effecten van zandwinning op biota nabij de kust en in de Waddenzee te simuleren is het rooster daar veel fijner dan verder op de Noordzee. Voor deze studie heeft dat tot gevolg dat sommige windparken die als bronlocatie zijn onderzocht in groter detail in het model zitten dan andere parken. Door het curvi-lineaire grid zijn de cellen niet uniform van grootte. In het fijnschalige deel zijn de roostercellen in de orde van enkele honderden meters in doorsnee, verder op in de Noordzee wordt dit enkele kilometers. In het fijnschalige grid kan dus wel enige differentiatie aangebracht worden t.a.v. de locatie binnen een windpark m.b.t. het loslaten van larven, maar het model is in het algemeen te grof om op het niveau van individuele turbines een uitspraak te doen over succesvolle rekrutering van oesters.

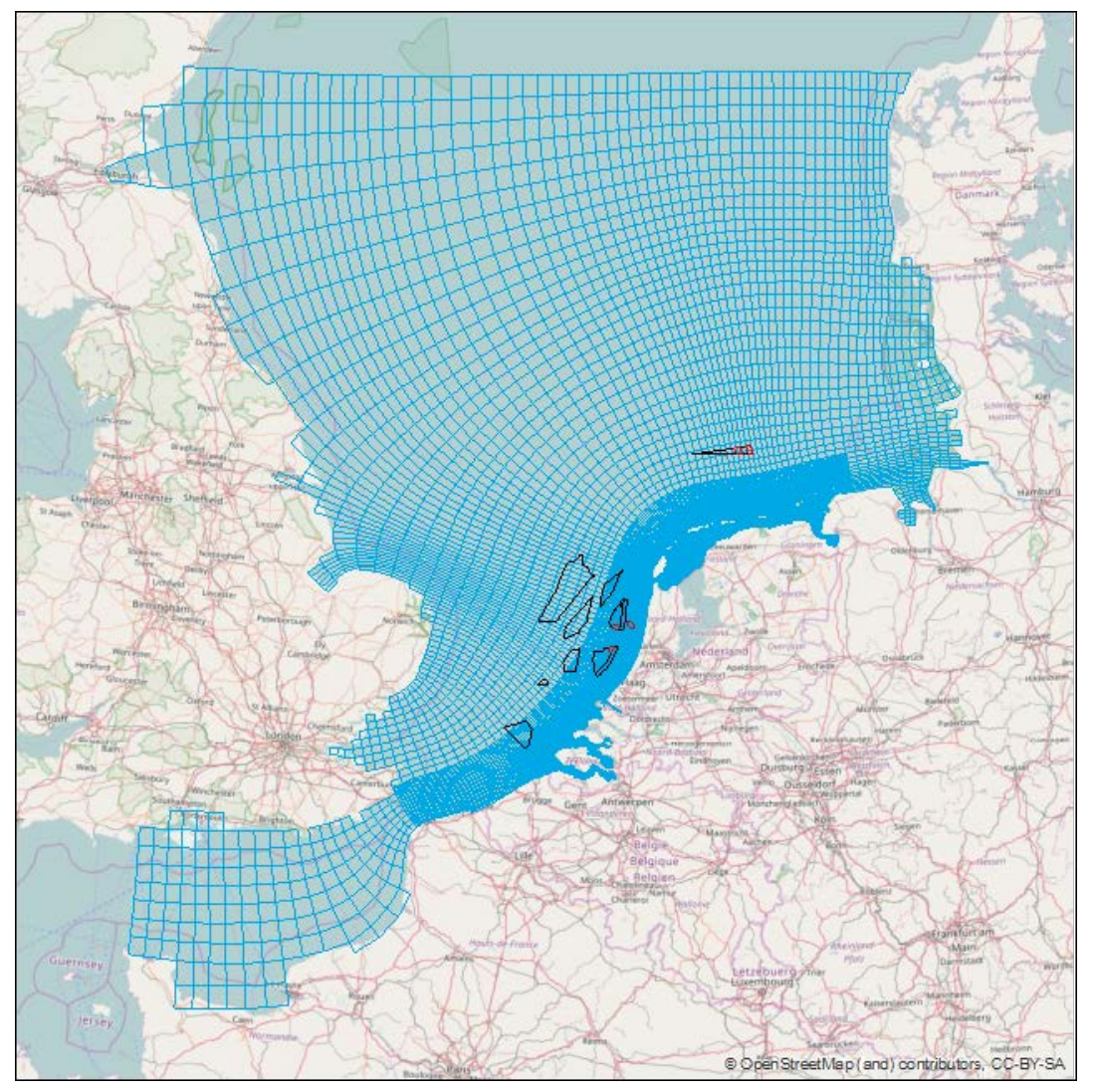

Figuur 3.4.1.1: ZUNO-DD-grid in het zuidelijk deel van de Noordzee en het Kanaal, met daarin aangegeven de ligging van de windmolenparken. 
Hydrodynamische gegevens zijn beschikbaar voor de jaren 2003 t/m 2011 en bevatten waterstanden, stroomsnelheden, watertemperatuur en saliniteit. De randvoorwaarden (forcing functions) voor de simulaties met het hydrodynamische model zijn gebaseerd op actuele gegevens, zoals rivierafvoeren, watertemperatuur en windgegevens. De 9 jaar aan data vormen dus een goed overzicht van de jaarlijkse variaties van de stroming. Het deeltjesmodel (D-PART) dat door de stroming wordt aangedreven is ook onderdeel van de Delft3D-modelsuite. In een deeltjesmodel wordt een groot aantal deeltjes gebruikt voor het simuleren van de larven. Deze deeltjes worden getransporteerd door de waterbeweging en dispersie-/diffusieprocessen. Elk deeltje in het model wordt gedurende een modelsimulatie in 3 dimensies gevolgd waardoor een goed beeld ontstaat van de verspreiding. In deze studie zijn larven als passieve deeltjes gemodelleerd.

\subsubsection{Uitgangspunten van het deeltjesmodel}

De uitgangspunten die in het model worden gehanteerd zijn randvoorwaarden voor de interpretatie van de resultaten. De verspreiding van de larven vanuit gegeven bronlocaties heeft als doel om

1) in te schatten in hoeverre een bepaalde bronlocatie zelfvoorzienend kan zijn m.b.t. larvenaanvoer en rekrutering in de populatie en

2) de kans in te schatten dat deze locatie als bronlocatie voor ander potentieel gunstig habitat kan dienen, in het bijzonder andere windparken.

Een belangrijk gegeven is hierbij rond welke leeftijd de larven zich gaan vestigen. Binnen deze studie wordt een leeftijd van maximaal 10 dagen gehanteerd vanaf het moment dat de larve het moederdier verlaat. Dit betekent dat wanneer de deeltjes ouder zijn dan 10 dagen deze uit het model worden gehaald en verder geen rol meer spelen in de modelsimulatie. Deze leeftijdsgrens beperkt dan ook het mogelijke verspreidingsgebied. Verder is aangenomen dat larven die jonger zijn dan 10 dagen zich nog niet kunnen vestigen. Hier is in de naverwerking van de modelresultaten rekening mee gehouden.

Binnen de huidige studie werd een eventueel gedrag van de larven (bijvoorbeeld actieve verticale migratie door de larven) niet in het model meegenomen. Verticaal transport was in de simulatie alleen mogelijk door advectie (stroming) en dispersie.

De wijze waarop de deeltjes in het model worden gebracht is zoveel mogelijk in overeenstemming met gegevens die zijn verzameld uit larventellingen gedurende het seizoen (data Kamermans). Dit levert de modelwaarden van de relatieve bijdrage van larvenproductie in de Noordzee als functie van de tijd zoals in fig 3.4.2.1.

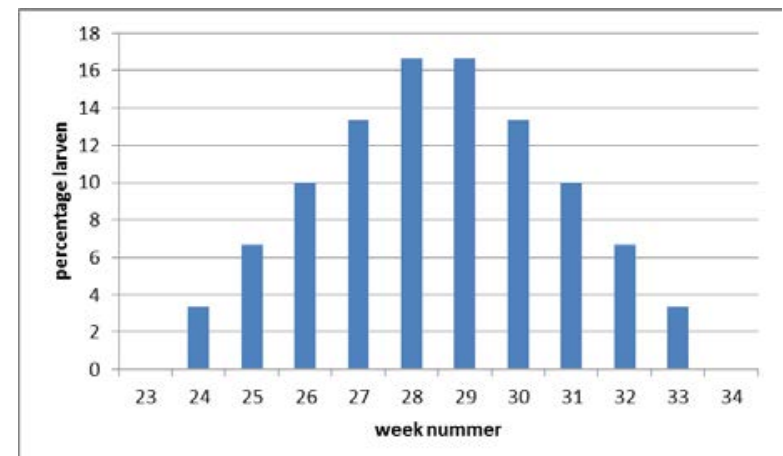

Figuur 3.4.2.1: Modelwaarden voor de relatieve larvenproductie in de Noordzee gedurende de zomerperiode zoals gehanteerd in deze studie. 
Deze relatieve verdeling is vervolgens omgezet naar het loslaten van de larven door de ouderdieren in het model. In het deeltjesmodel worden standaard $1.26 \times 10^{8}$ deeltjes nabij de bodem geïntroduceerd. Dit aantal van $1.26 \times 10^{8}$ is een arbitrair getal. Concentraties in de onderste waterlaag op de bestemming zijn gerelateerd aan dit aantal deeltjes en om het te kunnen koppelen aan het aantal daadwerkelijk vrijgekomen larven (nlarv) zal een schaling moeten worden toegepast van nlarv/1.26 x 108). Zoals in $\mathrm{H} 1.3 .3$ is beschreven groeien de larven van de platte oester de eerste dagen op binnen de schelp van de moeder, van waaruit ze worden losgelaten als ze voldoende gegroeid zijn.

Het model geeft geen absolute concentraties aan, maar wel de relatieve concentratie ten opzichte van de totale hoeveelheid larven die vanuit een bepaald gebied worden gegenereerd. In het model wordt ook geen rekening gehouden met de overlevingskans, alle deeltjes die in het model worden losgelaten worden verondersteld de volledige 10 dagen te overleven. Er wordt tevens van uitgegaan dat larven zich kunnen vestigen als ze 10 dagen oud zijn en niet jonger. Vandaar dat, om de vestigingskans in te schatten, de gemiddelde verspreiding van larven die 10 dagen oud zijn als modelresultaat wordt gezien.

Voor elke bronlocatie in het model worden de deeltjes nabij de bodem in het model losgelaten. Dit is realistisch, aangezien de bron (volwassen platte oesters) zich ook op de bodem bevinden. De resultaten die een maat opleveren van de aanwezigheid van larven in een gebied beperken zich dan ook tot de bodemlaag. De resultaten worden formeel als eenheden per $\mathrm{m}^{3}$ weergegeven maar aangezien de analyse wordt uitgevoerd voor de onderste waterlaag kan dit ook worden gezien als larven die zich op de bodem kunnen vestigen. In dat geval wordt de eenheid omgezet tot eenheden per $\mathrm{m}^{2}$.

\subsubsection{De brontermen}

De bronnen van de larven zijn gebaseerd op de lijst van windparken die ook in figuur 1 zijn opgenomen. Hier zijn gebieden uit geselecteerd die de hoogste analyse-prioriteit zijn toegewezen (zie Hoofdstuk 2). De gebieden die in deze studie zijn opgenomen als bron zijn:
1. Borssele
2. Buitengaats
3. Egmond aan Zee
4. Hollandse Kust Noord
5. Hollandse Kust Zuid
6. Luchterduinen
7. Prinses Amalia
8. Zee-energie

Voor elk gebied is 1 lozingspunt gecreëerd, aangegeven in onderstaande figuur. 


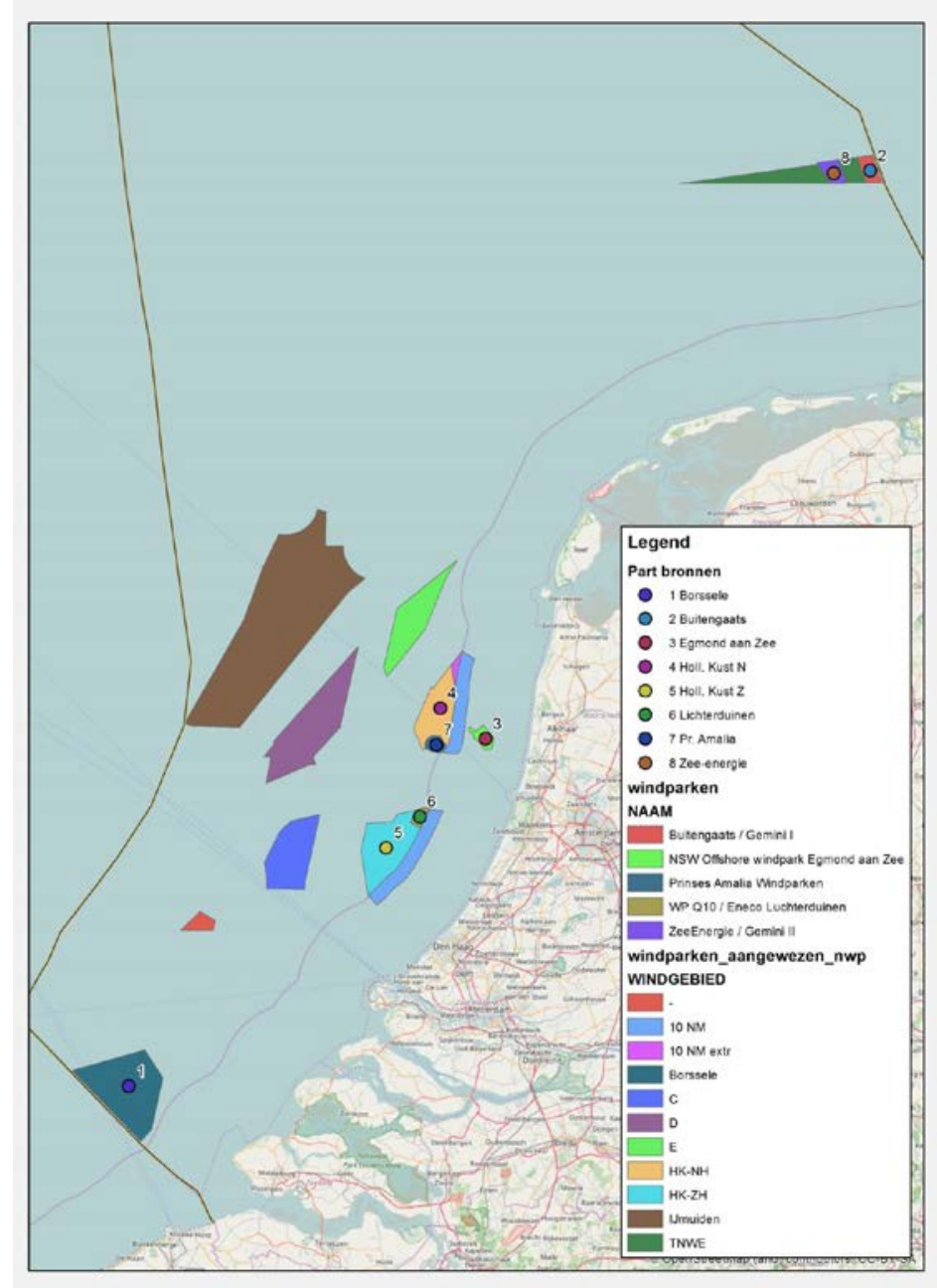

Figuur 3.4.3.1: Lozingspunten in windparklocaties voor simulaties larventransport in de Noordzee en Noordzeekustzone.

De simulaties zijn voor een periode van ongeveer drie maanden gedraaid voor elk van de 9 beschikbare jaren. Vervolgens is in de onderste waterlaag (bij de bodem) gekeken wat de gemiddelde verspreiding is van de larven die 10 dagen oud zijn. Op elk lozingspunt wordt een totale hoeveelheid larven losgelaten, afgeleid van de procentuele flux per week (Fig 3.4.2.1). Het resultaat wordt in beginsel uitgedrukt in eenheden per $\mathrm{m}^{3}$, maar wanneer wordt aangenomen dat de larven in de onderste laag zich kunnen vestigen kan dat worden vertaald in eenheden per vierkante meter hetgeen als maat kan worden gehanteerd voor de vestigingskans van de larven. Als bijvoorbeeld in de periode van 3 maanden $1 \times 10^{10}$ larven vrijkomen, moet de uitvoerconcentratie worden geschaald met $1 \times 10^{10} / 1.26 \times 10^{8}=79.2$, zoals aangegeven in $\mathrm{H}$ 3.4.2. Het resultaat is dan aantal per $\mathrm{m}^{2}$ (op de bodem). Indien een schatting kan worden gemaakt van de hoeveelheid geproduceerde (overlevende) larven dan kan dus via opschaling een vertaling worden uitgevoerd naar het aantal larven dat zich kan vestigen (bij geschikte habitat), per vierkante meter. Dit is wel een gemiddelde over de periode van drie maanden en, moet dus meer als maat worden gezien voor de vestigingskans. De mogelijke tijdvariatie van de concentratie van de 10 dagen oude larven is niet uitgewerkt. 


\subsection{Kritische massa}

De hoeveelheid oesters nodig voor de productie van een dusdanige hoeveelheid larven dat er kans is op succesvolle vestiging van larven en overleving van broed in de bank van herkomst, wordt aangeduid als de kritische massa. Dit is met behulp van het larvenmodel nagegaan door te berekenen welke hoeveelheid c.q. welk areaal aan oesters nodig is in een bepaald brongebied om in hetzelfde of nabij gelegen gebied - het vestigingsgebied - succesvolle vestiging te krijgen van oesterlarven.

Daarbij is uitgegaan van:

$=$ dichtheid oesters per $\mathrm{m}^{2}=50$ (zie resultaten Oester Voordelta; Smyth et al, 2016)

$=$ aantal larven per vrouwtjes oester $2 \times 10^{6}$ (zie Helm et al, 2004)

= overleving van de larven in 10 dagen $30 \%$ (zie Helm et al, 2004)

$=$ minimaal noodzakelijke larvenconcentratie van 50 per $\mathrm{m}^{3}$ in het vestigingsgebied (zie Kamermans et al, 2003)

Met het huidige model kunnen geen absolute waarden worden berekend van de kritische massa omdat er nog teveel aannames gedaan moeten worden om tot interpreteerbare uitkomsten te komen. Dit betreft naast bovengenoemde aannames het gedrag van de oesterlarven (zie o.a. Fuchs et al, 2013; Smyth et al, 2016). Deze zijn nu als inerte partikels gemodelleerd terwijl ze in werkelijkheid een veel complexer gedrag vertonen. Daarom is ervoor gekozen de relatieve omvang te berekenen van het benodigde oesterbestand in de verschillende gebieden voor succesvolle rekrutering. 


\section{Resultaten}

\subsection{Habitateisen platte oester Noordzee}

Vier life-history-processen bepalen in belangrijke mate de voorwaarden voor een duurzame ontwikkeling van een platte-oesterbank: Overleving, Groei, Reproductie en Rekrutering (OGRR). Het voorkomen van platte oesters is afhankelijk van hoe de abiotische en de biotische omgevingsfactoren op deze vier processen van invloed zijn, zoals aangeduid in Tabel 3.1.1. Zoals blijkt uit het voorgaande hoofdstuk werken variabelen als stroomsnelheid en lokale bodemdynamiek interactief en dat geldt ook voor andere variabelen. De tolerantie van de oester voor deze factoren moet een venster opleveren waarbinnen het habitat geschikt geacht wordt voor de oester. Verder zijn er biotische factoren zoals predatie en competitie die op het lot van de oesterbanken invloed uitoefenen, maar daarvoor zijn geen tolerantiegrenzen te geven.

Tabel 4.1.1. geeft een overzicht van de tolerantiegrenzen van de belangrijkste kwantificeerbare - factoren. In de tekst wordt dit verder toegelicht en gekoppeld aan de Noordzeecondities.

Tabel 4.1.1. Relatieve geschiktheid van omgevingsfactoren voor platte oesters in de Noordzee gegeven de tolerantie van oesters voor de genoemde variabelen, $0=$ ongeschikt, $1=$ matig geschikt, 2 = geschikt. De eerste vijf omgevingsfactoren (groen) zijn gebruikt om de geschiktheid van de windparklocaties te evalueren (sectie 4.3).

\begin{tabular}{|c|c|c|c|c|}
\hline & omgevingsparameter & \multicolumn{3}{|c|}{ geschiktheid } \\
\hline & & $\mathbf{0}$ & 1 & 2 \\
\hline 1 & bo demschuifspanning $\left(\mathrm{N} / \mathrm{m}^{2}\right)$ & $>1$ & $>0.6$ & $0.25-0.6$ \\
\hline 2 & Bodemligging/beweging & $?$ & $\begin{array}{c}?>- \\
>0.8 \\
\mathrm{~cm} / \mathrm{dag}\end{array}$ & $<0.8 \mathrm{~cm} / \mathrm{dag}$ \\
\hline 3 & zwevendstofgehalte ( $\mathrm{mg} / \mathrm{l})$ & $>180$ & $60-180$ & $<60$ \\
\hline \multirow{2}{*}{4} & \multirow{2}{*}{ watertemperatuur $\left({ }^{\circ} \mathrm{C}\right)$} & \multirow{2}{*}{$<3,>30$} & $3-7$ & \multirow{2}{*}{$7-25$} \\
\hline & & & $25-30$ & \\
\hline \multirow[t]{2}{*}{5} & \multirow{2}{*}{ sedimentsamenstelling } & grof zand & fijn zand & \multirow{2}{*}{$\begin{array}{l}\text { stevig slibbig zand, } \\
\text { slibbig gravel met } \\
\text { schelpen, stenen }\end{array}$} \\
\hline & & $>210 \mu \mathrm{m}$ & $>63 \mu \mathrm{m}$ & \\
\hline 6 & waterdiepte ( $\mathrm{m}$ beneden NAP) & $<-80$ & 79 & $<-1$ \\
\hline 7 & saliniteit (\%o) & $<20$ & $20-25$ & $25-35$ \\
\hline 8 & voedsel conc (chl $\mu \mathrm{g} / \mathrm{l})$ & $?$ & $<1.68$ & $>1.68$ \\
\hline 9 & zuurstofgehalte (mg/l) & $<0.5$ & $>1.5$ & $>3,5$ \\
\hline 10 & stroomsnelheid (m/s) & $>0,8$ & $<0.25$ & $0.25-0,8$ \\
\hline 11 & predatie & & & \\
\hline 12 & competitie & & & \\
\hline
\end{tabular}




\subsubsection{Bodemschuifspanning}

Bodemschuifspanning is hier gebruikt als een maat voor lokale bodemdynamiek. De aanwezigheid van een lage bodemschuifspanning is voorwaarde voor vestiging van de oesters. De bodemschuifspanning is een functie van bodemruwheid en stroomsnelheid. De aanwezigheid van structuren (zoals epifauna, biogene riffen, lege schelpen) kan de bodemruwheid beïnvloeden. De waterbeweging door getij en golven is het sturende proces achter substraatdynamiek. Het substraat is meer of minder bewegelijk, afhankelijk van sediment, stroomsnelheid en aangevoerde golfenergie. De golfenergie wordt vaak uitgedrukt als orbitaalsnelheid: de snelheid net boven de bodem die waterdeeltjes krijgen door de golfwerking. De doorwerking van golven op de bodem is afhankelijk van de golfhoogte en van de diepte. In de kustwateren zijn de golven lager, maar vanwege de geringe diepte is de orbitaalsnelheid hoog. Offshore zijn golven weliswaar hoger, maar zijn alleen in ondiepe delen (zoals de Doggersbank) onder normale condities de golven voelbaar aan de bodem. De orbitaalsnelheid is meegenomen in de modellering van de bodemschuifspanning met golfwerking (zie Fig 4.2.1.1). Er zijn geen directe metingen van de tolerantiegrenzen van platte oester met betrekking tot bodemschuifspanning.

Daarom zijn de historische verspreidingsgegevens in Olsen (1883) vergeleken met de recente bodemschuifspanningskaarten, omdat het aannemelijk is de stromingspatronen niet ingrijpend zijn veranderd in de laatste 150 jaar. In de Noordzee ten noorden van de Waddeneilanden was er een grote aaneengesloten populatie die aan de zuidkant en oostkant vrij scherp begrenst wordt door de $0.6 \mathrm{~N} / \mathrm{m}^{2}$ contour van de gemiddelde bodemschuifspanning. Ook de Doggersbankpopulatie kwam voor in gebieden met een duidelijk lagere bodemschuifspanning. Voor de meer zuidelijke populatie bij de monding van het Kanaal en in het Kanaal is de situatie anders, daar kwamen langs de kust en meer offshore uitgebreide platte-oesterpopulaties voor in gebieden die nu een hogere gemiddelde en maximale bodemschuifspanning kennen. Wel is de maximale bodemschuifspanning in een aantal offshoregebieden duidelijk lager en meer vergelijkbaar met bijvoorbeeld de Centrale Oestergronden. In de monding van het Kanaal en in het Kanaal bevinden zich uitgebreide gebieden met hard substraat in de vorm van gravel. Het is mogelijk dat platte oesters dit substraat in voldoende mate kunnen benutten bij hogere bodemschuifspanning, maar hiervoor zijn geen onderzoeksgegevens beschikbaar. Op basis van deze gegevens nemen we aan dat gebieden met een bodemschuifspanning lager dan $0.6 \mathrm{~N} / \mathrm{m}^{2}$ in ieder geval geschikt zijn voor de ontwikkeling van platte-oesterbanken. De gebieden met een hogere bodemschuifspanning zijn matig geschikt voor de ontwikkeling van platte-oesterbanken, maar individuele oesters kunnen waarschijnlijk goed overleven. Het is niet goed mogelijk om aan te geven bij welke bodemschuifspanning een gebied ongeschikt is voor zowel individuele oesters als voor de vorming van oesterbanken. Dit is voor de huidige onderzoeksvraag met betrekking tot de geschiktheid van de windparklocaties minder relevant, omdat alle locaties een bodemschuifspanning hebben lager dan $1 \mathrm{~N} / \mathrm{m}^{2}$ : zie par 4.2 voor een meer gedetailleerde uitwerking. 


\subsubsection{Bodembeweging}

De bodemligging kan veranderen doordat er zandgolven optreden. Dit sedimenttransport is van belang voor vestiging en overleving van oesterbroed, en afhankelijk van de kritische bodemschuifspanning. Dit is de drempel waarboven het begint te bewegen en/of op te wervelen en wordt bepaald door de korrelgrootte van het sediment, de dichtheid van het sediment en de invloed van biota op de sedimentsterkte. Grant et al (1990) lieten in een laboratoriumexperiment zien dat lage gehaltes aan gesuspendeerd sediment door opwerveling van $0.1 \mathrm{~cm} /$ dag kunnen bijdragen aan de voedselopname, en zo een positief effect hebben op de groeisnelheid van Ostrea edulis, maar een toename van opwerveling van sediment tot $0.8 \mathrm{~cm}$ per dag leidde tot verminderde groei. Er wordt uitgegaan van een tolerantie voor bodembeweging van $0.8 \mathrm{~cm} /$ dag. In H 4.2 .3 wordt ingegaan op de modelberekeningen van de bodembeweging.

\subsubsection{Zwevendstofgehalte}

Het zwevendstofgehalte is van belang voor groei. Oesters filteren gesuspendeerd materiaal uit het water, dat bestaat uit fytoplankton, detritus en anorganisch materiaal. Ze benutten het fytoplankton voor de groei, maar het anorganisch materiaal kan niet voor het metabolisme benut worden. Neemt het gehalte aan anorganisch materiaal toe dan neemt de mogelijkheid voor groei af. Dit geldt voor de meeste filter feeders en ook voor platte oesters (e.g., Laing et al., 2005). Voor J apanse oesters (Crassostrea gigas) is experimenteel vastgesteld dat boven de $90 \mathrm{mg} / \mathrm{l}$ aan zwevend stof de groei sterk afneemt (Barillé et al., 1997). Metingen aan een opstelling in het veld van Sawusdee et al (2015) gaven aan dat totaal gesuspendeerd materiaal significant hoger is vlak bij de bodem (60 mg/l) in vergelijking met $80 \mathrm{~cm}$ daarboven $(40 \mathrm{mg} / \mathrm{l})$. Dit resulteerde in significant lagere filtratie-snelheden van Ostrea edulis, maar had na 15 maanden geen significant effect op de conditie van de oesters. In H 4.2.3 wordt ingegaan op de modelberekeningen van gemiddelde en maximale zwevend stof-gehalten.

\subsubsection{Watertemperatuur}

Watertemperatuur is vooral van belang voor reproductie. Gonadenontwikkeling vindt plaats tussen 7-14 ${ }^{\circ} \mathrm{C}$ (Lubet, 1976). Overleving en groei van larven wordt geobserveerd tussen 10-31 ${ }^{\circ} \mathrm{C}$ met een optimum van $25-27{ }^{\circ} \mathrm{C}$ (Davis \& Calabrese, 1969). Broedval wordt gevonden vanaf $18.5^{\circ} \mathrm{C}$ (Hoek, 1902). Overleving van broed vereist een watertemperatuur van meer dan $3{ }^{\circ} \mathrm{C}$ Child \& Laing (1998). Overleving van adulten neemt af boven $30^{\circ} \mathrm{C}$ (Haure et al., 1998). Hierbij geldt wel dat populaties zich kunnen aanpassen aan de lokale watertemperatuurranges. Verder geldt dat de productie van larven meer omvangrijk is bij een watertemperatuur boven het minimum van $18.5^{\circ} \mathrm{C}$.

De gemodelleerde watertemperatuurranges in de Noordzee zijn weergegeven in figuur 4.1.1. Hieruit blijkt dat de watertemperatuur in principe geen beperkende factor is voor overleving, mogelijk wel voor reproductie. 

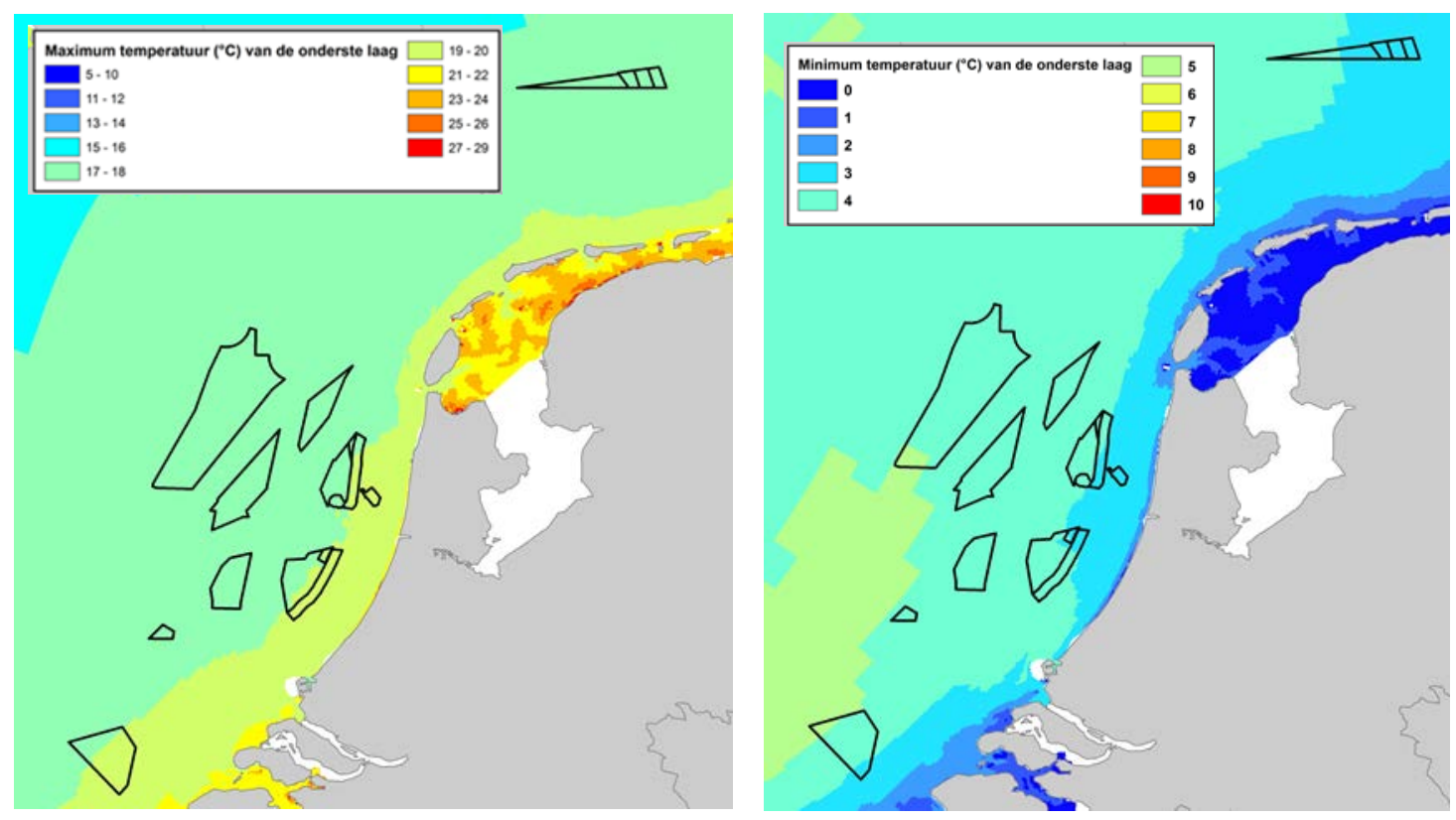

Figuur 4.1.1. Maximum- en minimumwatertemperatuur bij de bodem op jaarbasis

\subsubsection{Sedimentsamenstelling}

Sedimentsamenstelling is van belang als substraat voor rekrutering. Allereest zijn schelpen en bestaande oesterbanken goed voor rekrutering. Bij afwezigheid daarvan geldt de korrelgrootte van het sediment als meest gebruikte parameter. Deze is vrij eenvoudig te bepalen. Ruimtelijke patronen in het voorkomen van schelpdieren correleren vaak met de korrelgrootte van het sediment, maar er is weinig bewijs dat dit de sturende factor is. Andere factoren die covariëren met korrelgrootte zijn waarschijnlijk veel belangrijker (Snelgrove \& Butman 1994). De waterbeweging kan de sedimentsamenstelling bepalen doordat zware deeltjes eerder uitzinken dan lichte. Op beschutte plaatsen vind je dan meer slib, terwijl het sediment grover is op onbeschutte plaatsen. De korrelgrootte is over het algemeen een reflectie van de gemiddelde lokale stroming. Houziaux et al (2011) hebben een reconstructie gemaakt van sedimentsamenstelling van de Belgische kust honderd jaar geleden. Zij beschrijven de bodem waar voor 1860 uitgestrekte oesterbedden op voorkwamen als volgt: een heterogeen gravelveld, gedeeltelijk bedekt met een dunne laag $(<15 \mathrm{~cm})$ zand waar stukken steen uitstaken. Wasson (2010) onderzocht factoren die de verspreiding van de Olympia oester (Ostrea lurida) konden verklaren in een estuarium in Californië. Overleving van de oesters op kleine harde substraten werd belemmerd door begraving door fijn sediment. Op hele slibrijke locaties werden oester alleen aangetroffen op grote rotsen. In de noordwestelijke Middellandse Zee wordt aangroei op scheepswrakken gedomineerd door Ostrea edulis (Peirano, 2013). Op basis van deze verspreidingsgegevens wordt grof zand (korrelgrootte $>210 \mu \mathrm{m}$ ) als ongeschikt, fijn zand (korrelgrootte $>63 \mu \mathrm{m}$ ) als matig geschikt en stevig slibbig zand, slibbig gravel met schelpen en stenen (dit is niet gedefinieerd in korrelgrootte) als geschikt geclassificeerd. Uit fig 4.1.2 blijkt dat slibrijk zand alleen voorkomt op de noordelijke windparklocaties. De bodem in de andere windparklocaties bestaat voornamelijk uit fijn zand. 


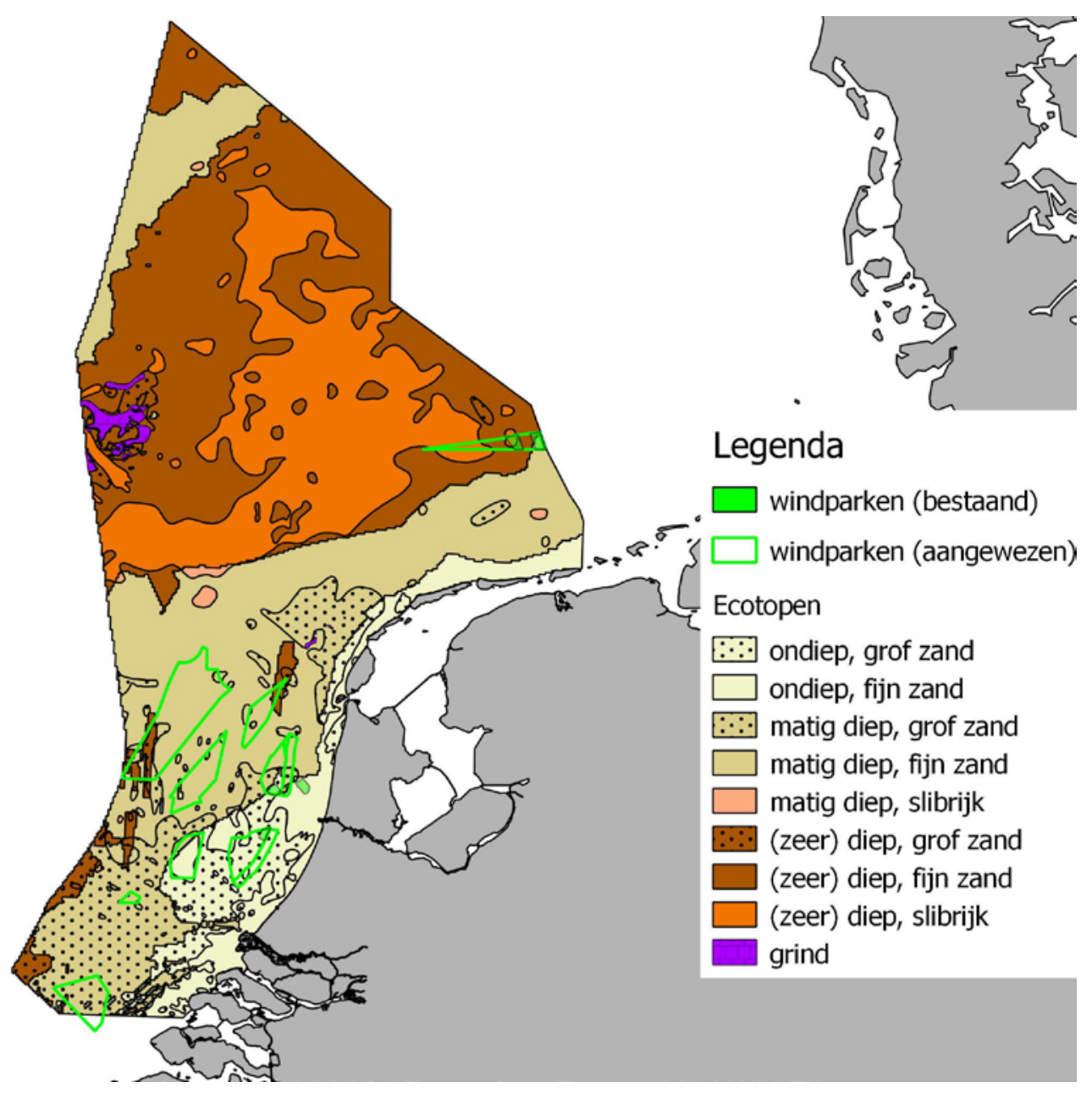

Fig 4.1.2 Sedimentsamenstelling NCP (I cona, 1992).

\subsubsection{Waterdiepte}

Waterdiepte is van belang voor overleving. In het intergetijdegebied is de droogligduur gemaximeerd in verband met de voedselbeschikbaarheid ; in dieper water kan voedsel- en zuurstoftoevoer beperkend zijn. Platte oesters komen in estuaria (inshoregebieden) voor tot in de laag-laagwaterzone (maximaal - 1 m NAP) (Montes et al. 1991). In de offshore- en nearshore-gebieden kunnen platte oesters voorkomen tot $80 \mathrm{~m}$ diep (Hayward \& Ryland, 1998). Dit betekent dat de meeste gebieden op het NCP in beginsel geschikt zijn voor platte oester voor wat betreft diepte (zie Fig 4.1.3). 


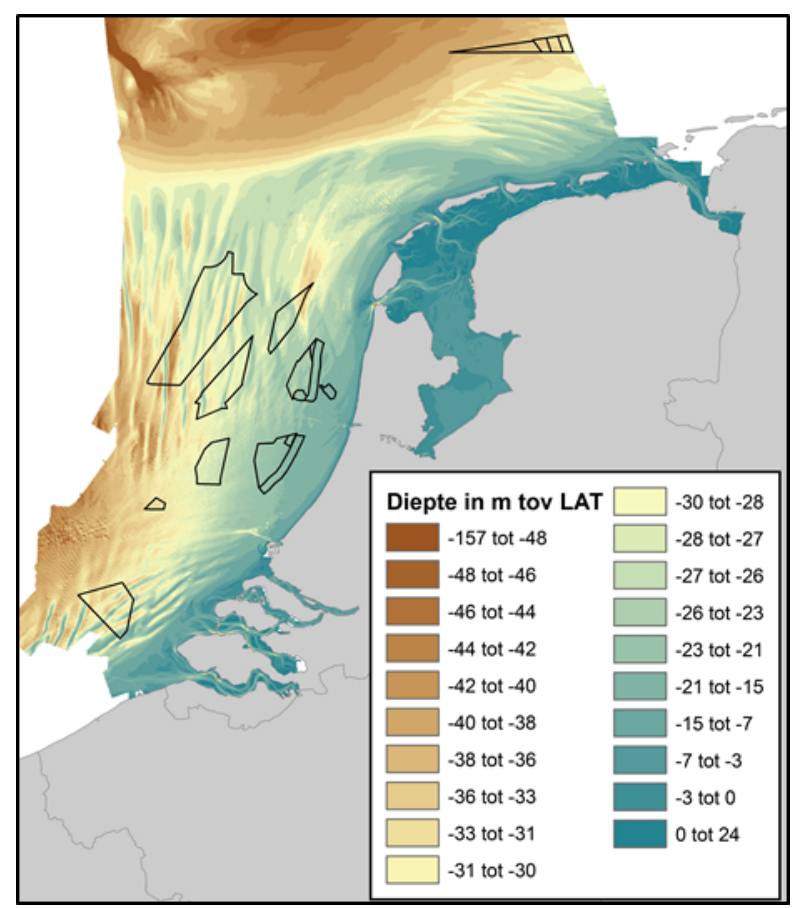

Figuur 4.1.3. Windparklocaties in relatie tot diepte (in $\mathrm{m}$ ) in het NCP.

\subsubsection{Saliniteit}

Voor overleving van oesterlarven en groei is een saliniteit van 25 - 30 \%o optimaal en een saliniteit tussen 20 en $25 \%$ als suboptimaal en beneden $20 \%$ als ongeschikt (Davies \& Ansell, 1962). De windparklocaties in het Nederlandse deel van de Noordzee hebben allen een geschikte saliniteit: Fig 4.1.4.
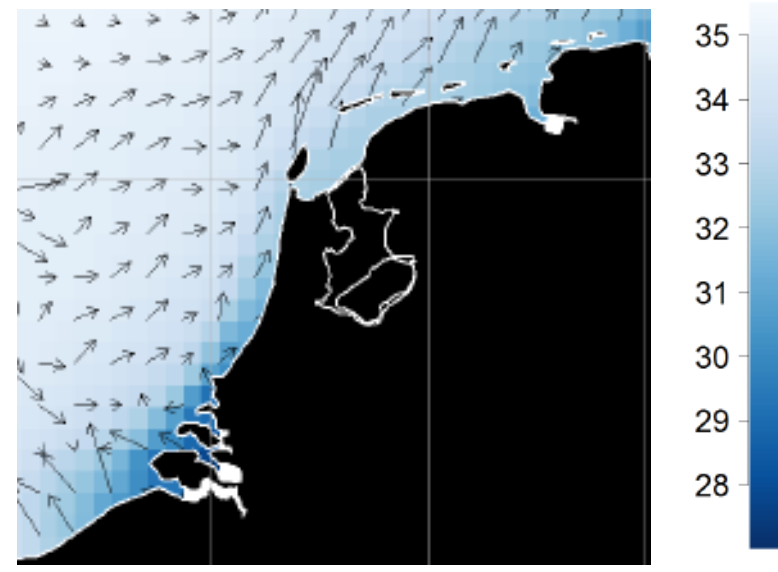

Figuur 4.1.4. Saliniteit en waterstroming (Herman et al, 2014)

\subsubsection{Voedselaanbod}

Voedselaanbod is van belang voor groei en wordt uitgedrukt als de hoeveelheid chlorofyl per liter. Uit hatchery-onderzoek blijkt dat voor voortplanting 1,68 $\mathrm{mg} / \mathrm{l}$ optimaal is (Millican \& Helm (1994). Goede groei wordt bereikt wanneer er $>0.5 \mu \mathrm{g} / \mathrm{l}$ aanwezig is (Yildiz et al, 2011). Figuur 4.1.5. laat zien dat ondiepere wateren meer voedsel bevatten dan offshore, maar dat ook daar voldoende voedsel aanwezig is. Er kan van worden uitgegaan dat het aanbod van fytoplankton in 
het grootste deel van het jaar in alle windparklocaties voldoende is voor groei en voortplanting van platte oesters (Fig 4.1.4).

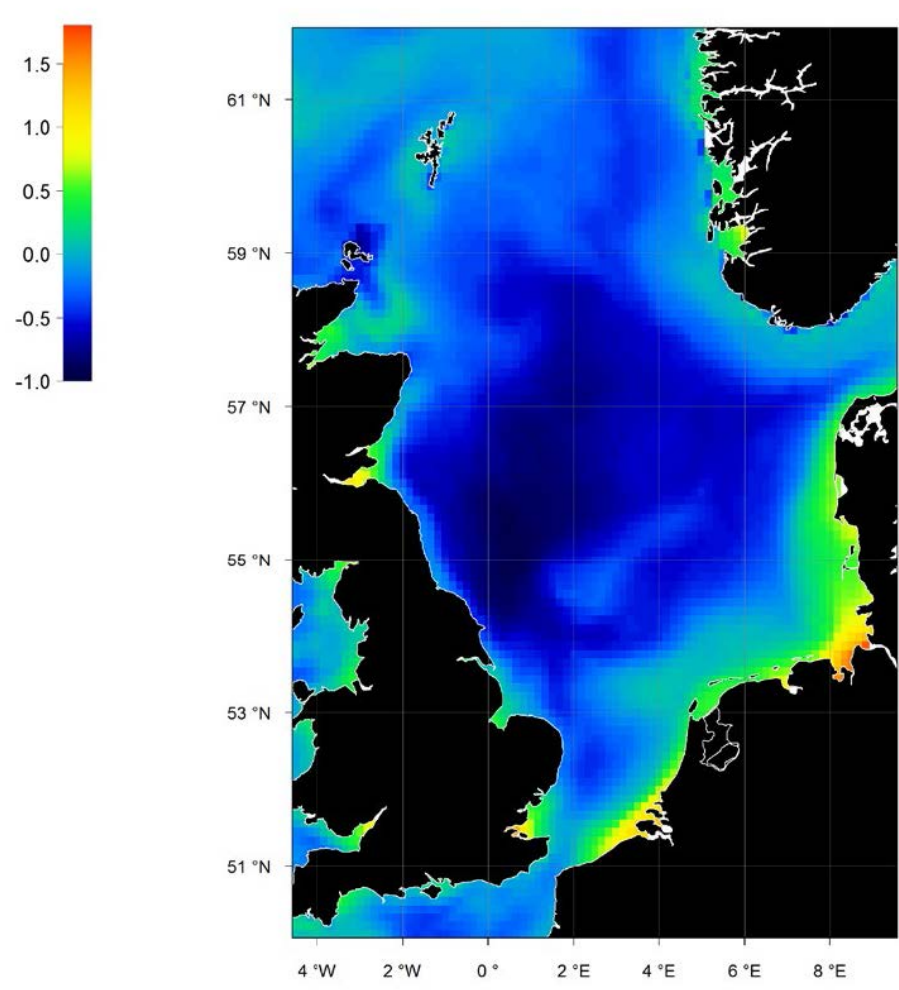

Figuur 4.1.5. Langjarig gemiddeld chlorofylgehalte in bovenste $10 \mathrm{~m}$ van de waterkolom $(\mu \mathrm{g} / \mathrm{l})$. De figuur gebruikt een logaritmische schaal, $0=1 \mu \mathrm{g} / \mathrm{l}$ en $1=10 \mu \mathrm{g} / \mathrm{l}$. (uit: Herman et al 2014).

\subsubsection{Zuurstofgehalte}

Het zuurstofgehalte is van belang voor de overleving. Tweekleppige schelpdieren kunnen weliswaar enige tijd overleven zonder zuurstof omdat ze zijn aangepast aan tijdelijke droogstand bij laagwater. Ze sluiten dan de schelp en gaan over op ademhaling zonder zuurstof te gebruiken. Bij lage temperatuur kunnen ze dit een aantal dagen volhouden, waardoor ze droog bewaard kunnen worden. Onder Noordzeeomstandigheden is er geen droogstand en is er niet de trigger om de schelp te sluiten. Dan is het minimumzuurstofgehalte voor overleving voor korte duur 0.5 mg/l (Davis, 1975). Uit de review van Vaquer-Sunyer \& Duarte (2008) blijkt dat de LC 50, de concentratie waarbij $50 \%$ van de dieren overleeft voor tweekleppigen 1,5 mg/l bedraagt voor de duur van 412 uur. De LC 90, waarbij 90 \% overleeft bedraagt 3.5 mg/l. Omdat het water op de windparklocaties goed gemengd is, treedt er geen gelaagdheid op en is er geen risico op te lage zuurstofgehaltes.

\subsubsection{Stroomsnelheid}

Stroomsnelheid is van belang voor rekrutering, en voor voedsel- en zuurstoftoevoer. Platte oesters kunnen ook bij hoge stroomsnelheden goed groeien en overleven, zoals op de Noordzee experimenteel is vastgesteld (Pogoda et al., 2011). Dit hangt wel af van het type substraat. Op harde ondergrond geldt een veel hogere tolerantie dan op zacht substraat. Drinkwaard (1961) geeft aan dat platte oesters in de toenmalige Oosterschelde op zacht substraat een 
stroomsnelheid beneden $0,25 \mathrm{~m} / \mathrm{s}$ nodig hebben met een optimum rond de 0,03 m/s. Deze preferentie hangt vooral samen met de beperkte dispersie van platte-oesterlarven. Oesterlarven vestigen zich bij voorkeur op of dichtbij bestaande oesterbanken. Een lage stroomsnelheid is daarvoor een belangrijke voorwaarde. De historische gegevens laten echter zien dat platte oesters op de geulranden voorkomen en daar goede groei lieten zien bij veel hogere stroomsnelheden (Gercken \& Schmidt, 2014). Verder voorkomt een relatief hoge stroomsnelheid dat oesters de sedimentatie van slib niet kunnen bijhouden. Op basis van deze gegevens en de verspreiding op oude kaarten is een optimale stroomsnelheid ingeschat tussen 0,25 en $0,6 \mathrm{~m} / \mathrm{s}$, hogere stroomsnelheden als ongeschikt (voor vestiging van larven) en lagere stroomsnelheden als suboptimaal (door hogere sedimentatiesnelheid).

\subsubsection{Predatie}

De afwezigheid van predatie is van belang voor de overleving. Jonge platte oesters zijn kwetsbaar voor predatie totdat ze ongeveer $3 \mathrm{~cm}$ groot zijn, vooral doordat de schelp nog dun is (Gercken \& Schmidt, 2014). Belangrijke generalistische predatoren voor dit stadium zijn zeester (Asterias rubens), wulk (Buccinum undatum), purperslak (Nucella lapillus) en grote, mobiele kreeftachtigen zoals strandkrab (Carcinus maenas) en Noordzeekrab (Cancer pagurus).

Daarnaast is er een aantal soorten roofslakken dat meer gespecialiseerd is op oesters (vooral de jonge oesters), zoals de geschubde stekelhoren (Ocenebra erinacea), een inheemse soort, en de uitheemse Amerikaanse oesterboorder (Urosalpinx cinerea) en Japanse stekelhoren (Ocinebrellus inornatus). De laatste twee zijn invasieve exoten die recentelijk in de Delta (Oosterschelde, en de Japanse stekelhoren tevens in het Grevelingenmeer) zijn vastgesteld. Deze roofslakken zijn afhankelijk van hard substraat om eieren af te zetten en hebben geen pelagische larven. Ze verspreiden zich waarschijnlijk nauwelijks over zacht sediment (Didderen \& Gittenberger, 2013). Daardoor is de kans dat ze offshoreplatte-oesterbanken kunnen koloniseren heel klein. De meeste generalistische predatoren, zoals zeesterren en krabben, komen algemeen voor in de Noordzee en er zijn geen gegevens die er op wijzen dat in de windparklocaties hierin afwijken.

\subsubsection{Competitie}

Competitie is van belang voor het inschatten van de overleving en groei kansen van de platte oester. Een aantal soorten ongewervelde organismen concurreert met platte oesters om voedsel (gedurende de gehele levenscyclus) en om ruimte. De meeste soorten schelpdieren die net zoals platte oesters op de bodem leven (epifauna) en fytoplankton filtreren (filter feeders) zijn voedselconcurrenten. In de diepere delen van de Noordzee kwamen die soorten vroeger talrijker voor, zoals paardenmossel (Modiolus modiolus), maar zijn nu grotendeels afwezig. Verder kan concurrentie optreden met stekelhuidigen (echinodermen), zoals de slangster Amphiura filiformis (Duineveld et al., 1987). Deze soort komt algemeen voor in de Centrale Oestergronden en elders in de diepere delen van de Noordzee tot in de Gemini-locaties (Duineveld et al., 1987). Deze soort heeft een vergelijkbare voorkeur voor slibrijke, diepere delen van de Noordzee, maar de mate waarin competitie optreedt is onbekend, doordat de platte oester al lang geleden uit dit gebied is verdwenen. 


\subsection{Modelsimulaties: bodemdynamiek en zwevend stof in de windparken}

\subsubsection{Bodemschuifspanning}

Bodemschuifspanning is altijd hoog in het Kanaal en rond de oostpunt van Engeland (Norfolk). Dit zijn locaties waar de stroming het grootst is. Daarnaast is bodemschuifspanning altijd relatief hoog in delen waar golven aan de bodem komen. Onder normale condities is dat vooral in de zeer ondiepe delen langs de kust (figuur 4.2.1.1). Onder stormcondities kunnen de waarden van de bodemschuifspanning makkelijk een orde van grootte hoger liggen. De verdeling waar maximale waarden optreden wordt in deze situatie sterk gedomineerd door de golven. Dit is goed te zien in de vergelijking tussen de figuren 4.2.1.2 en 4.2.1.3. Deze figuren verschillen eigenlijk alleen in het Kanaal en rond de oostkant van Engeland, waar gemiddeld hoge snelheden voorkomen en een deel van de bodemschuifspanning bepaald wordt door stroming. Op alle andere locaties is het patroon zeer vergelijkbaar, wat aangeeft dat golven echt de kracht op de bodem bepalen.

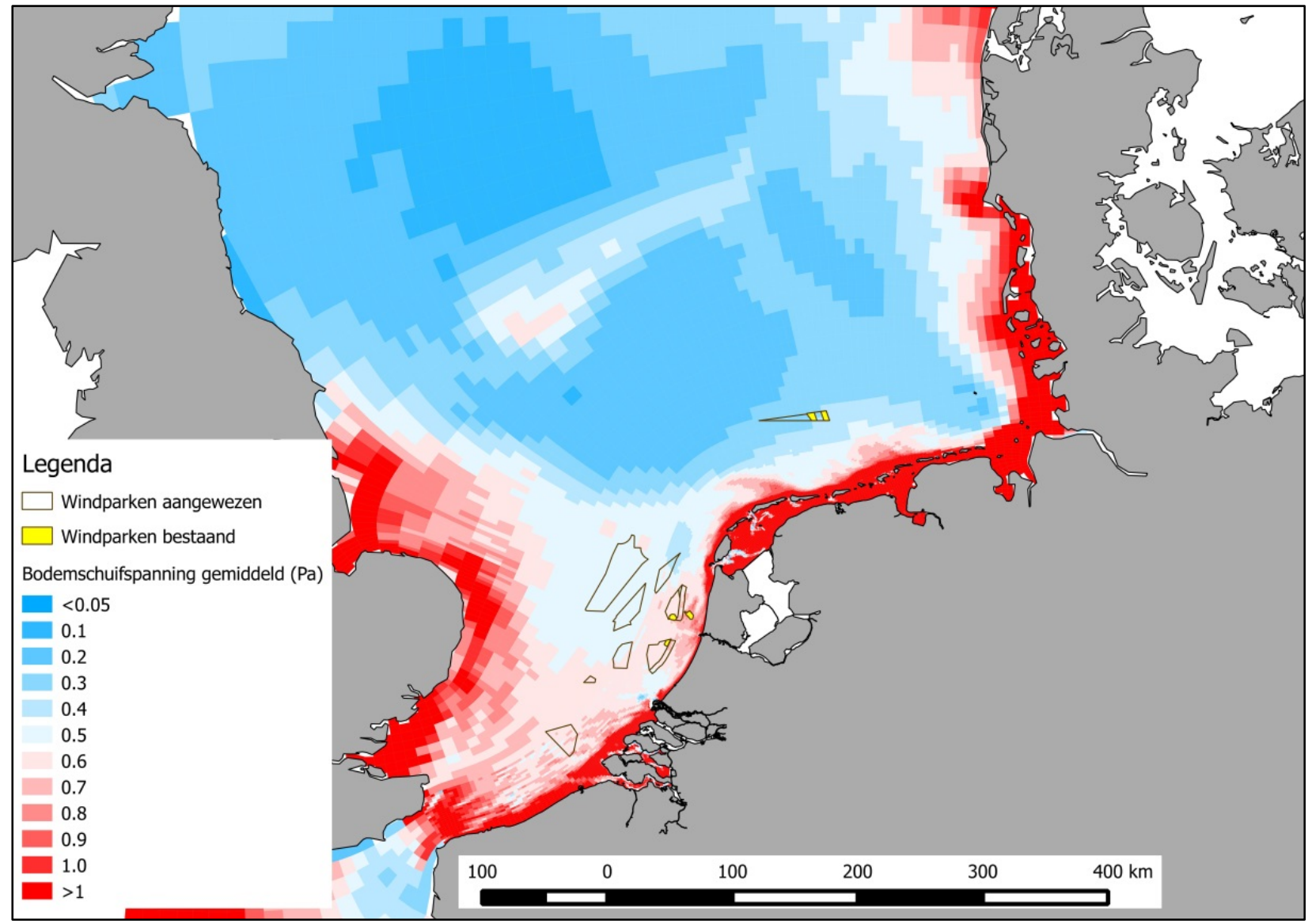

Fig 4.2.1.1. Gemiddelde bodemschuifspanning op de Noordzee (effect van stroming en golven gecombineerd) 


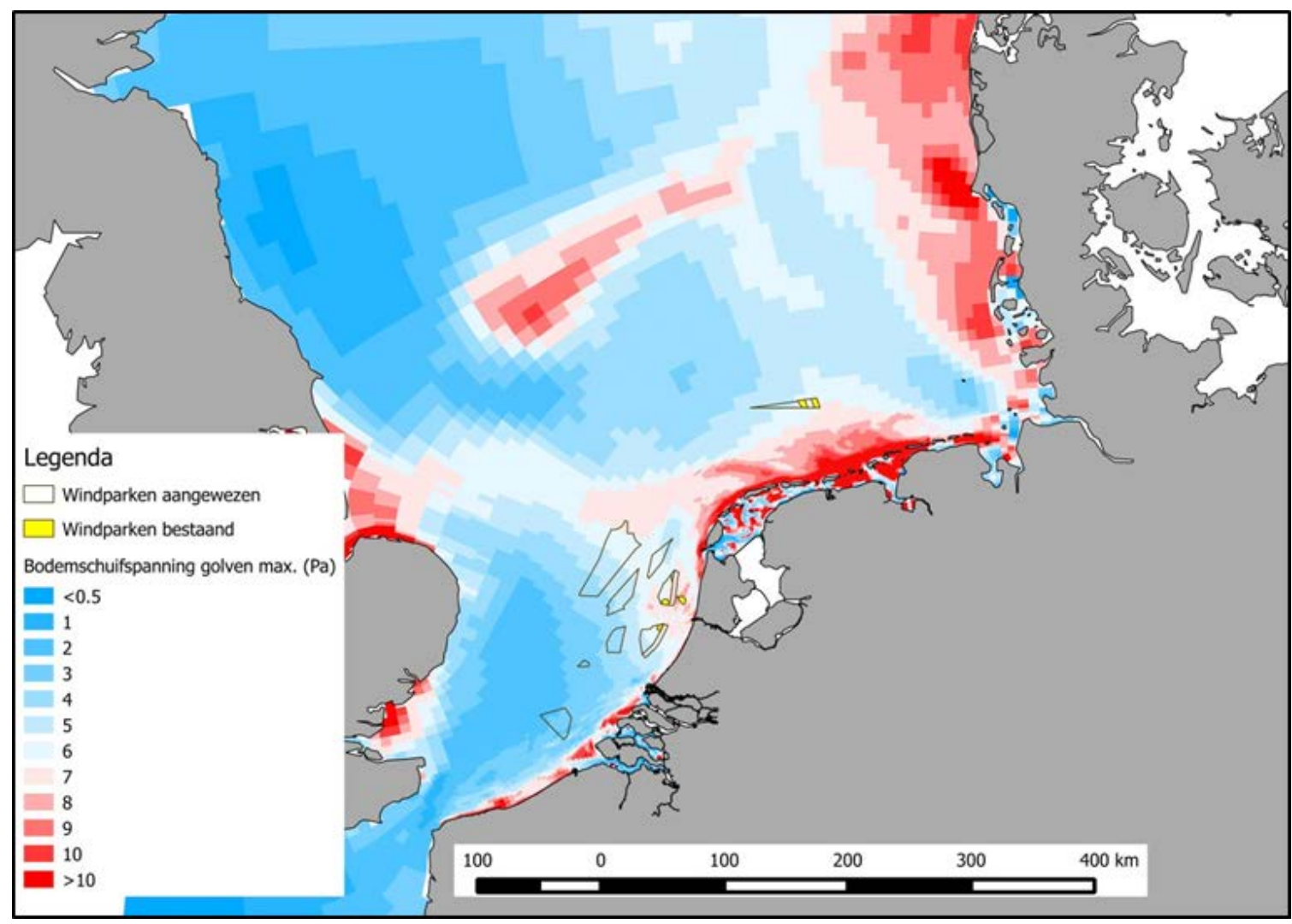

Fig 4.2.1.2. Windparklocaties in het NCP in relatie tot maximale bodemschuifspanning op de Noordzee (effect van golven en stroming gecombineerd). NB: De kleurschaal is een orde van grootte meer dan in fig. 4.2.1.1.

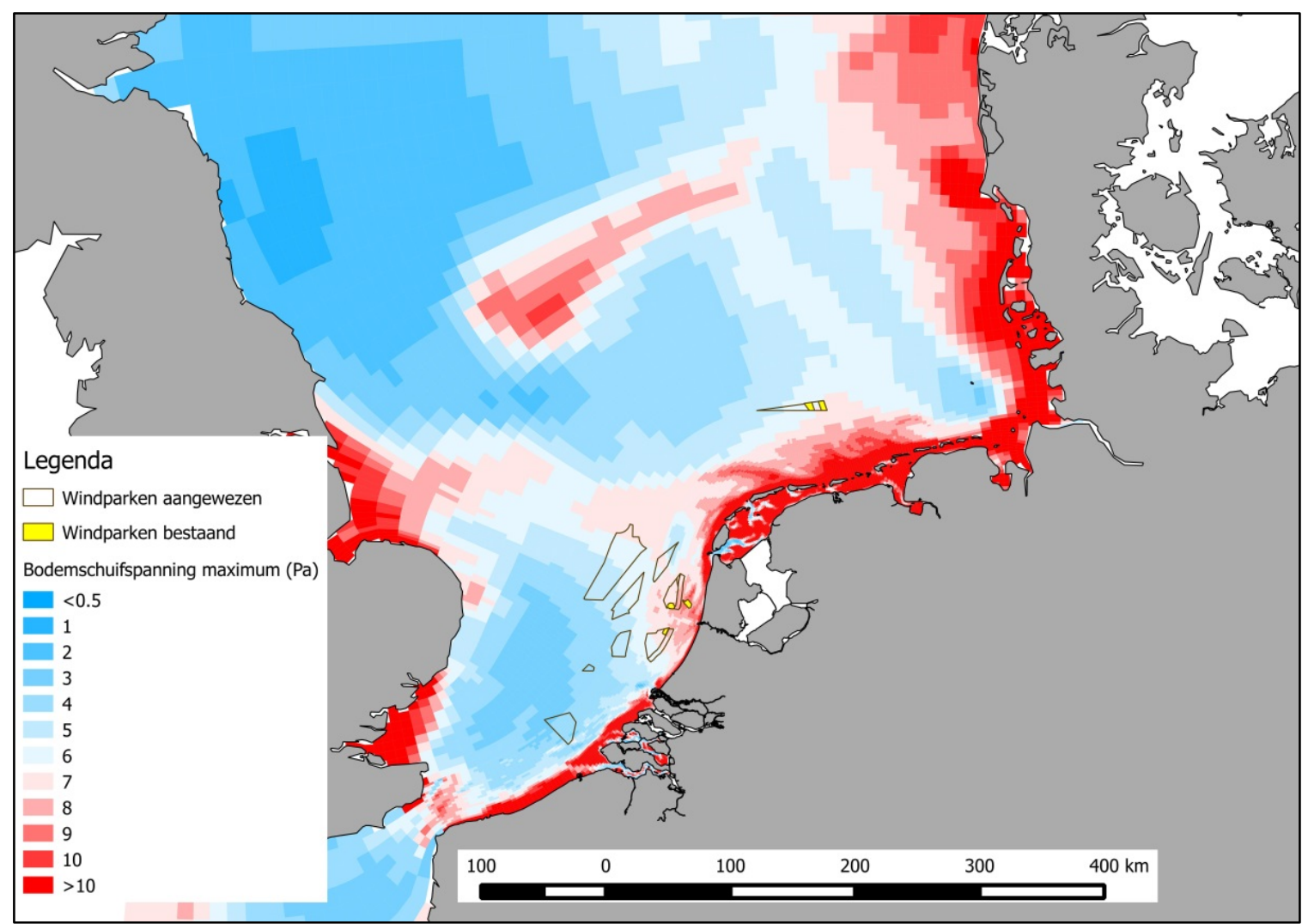

Fig 4.2.1.3. Windparklocaties in het NCP in relatie tot maximale bodemschuifspanning op de Noordzee (alleen het effect van golven). NB: De kleurschaal is hetzelfde als in fig. 4.2.1.2. 
In deze figuren valt onmiddellijk de locatie van de Doggersbank op. Een ondiep deel in de Noordzee dat daarmee sneller aan de impact van golven is blootgesteld. Als we de ruimtelijke verdeling van de bodemschuifspanning vergelijken met de historische verspreiding van oesters dan kan hier een indicatie uit verkregen worden omtrent het belang van de waterbeweging voor habitatgeschiktheid. In figuren 4.2.1.4 is de oude verspreidingskaart van oesters uit de Piscatorial Atlas van Olsen (1883) gefit op de modeldata van maximale bodemschuifspanning en de verdeling van de bodemschuifspanning van golven. Omdat de oude kaart een iets andere projectie heeft dan de modeldata lijkt deze hierdoor enigszins vervormd. Voor de volledigheid is ook de kaart van Olsen bijgevoegd in Fig 4.2.1.5.

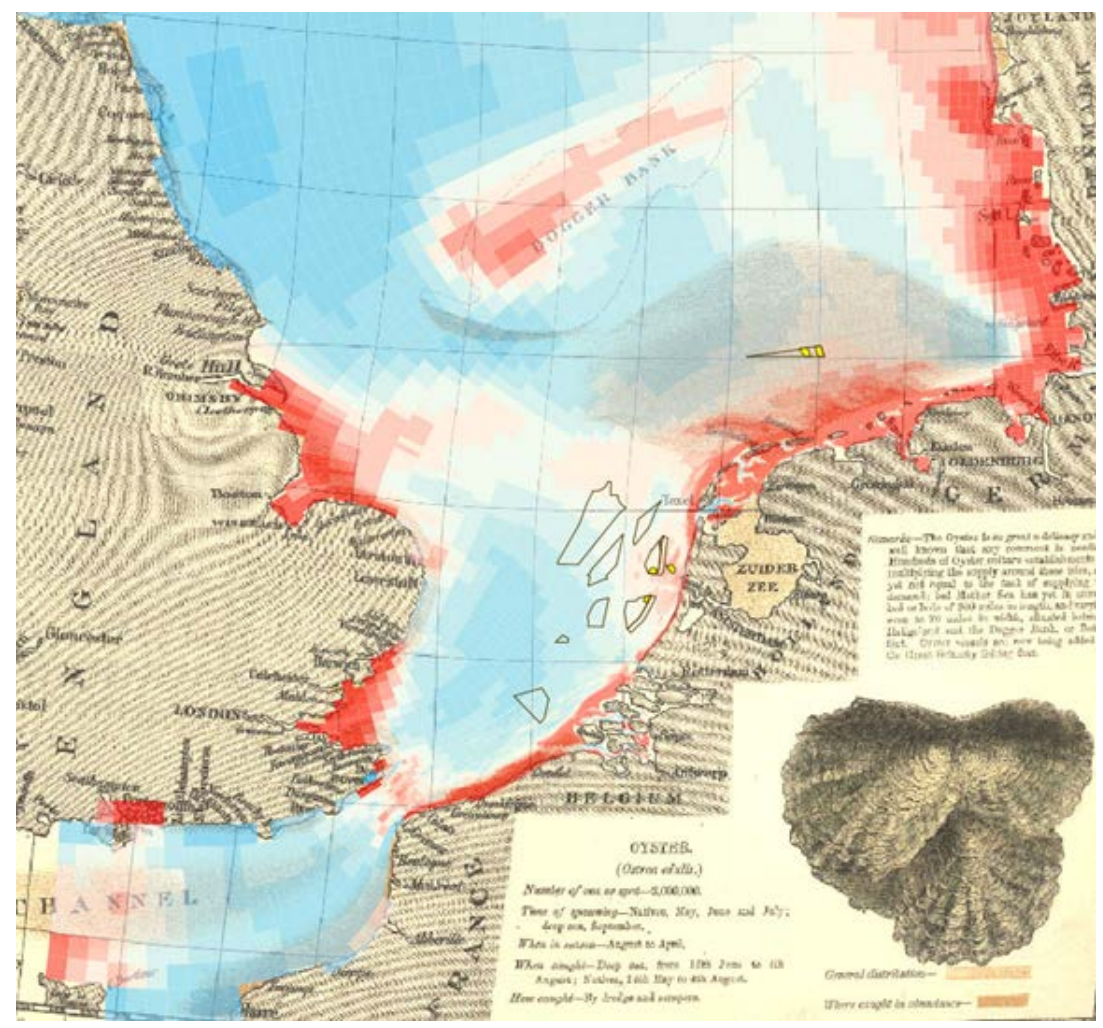

Fig 4.2.1.4. Windparklocaties in het NCP in relatie tot maximale bodemschuifspanning op de Noordzee en de historische verspreiding van oesters (Olsen, 1883). Legenda identiek aan figuur 4.2.1.2.

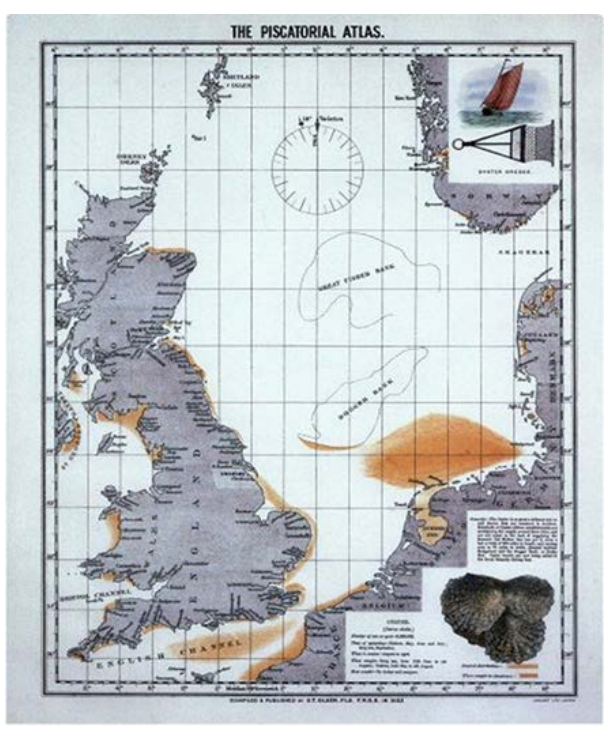

Figuur 4.2.1.5. Kaart uit de atlas van Olsen 1883 met in bruin de oestervoorkomens. 
Wat in deze vergelijking opvalt is dat platte oesters vroeger regelmatig voorkwamen in gebieden met een hoge stroomsnelheid bij de bodem. In het Kanaal, ten zuiden van Engeland, tot ook in het nauw van Calais werden relatief veel platte oesters aangetroffen. Dit zijn gebieden met een hoge stroomsnelheid (en bijbehorende bodemschuifspanning), maar wel gebieden waar golven niet erg tot de bodem doordringen (zie fig. 4.2.1.5). Er zijn geen gegevens uit de literatuur bekend van kritische waarden waarbij oesters in beweging komen. Dit zal tevens sterk afhankelijk zijn van de ondergrond (in hoeverre ze vast zitten aan hardsubstraat of andere oesters of los op sediment liggen).

\subsubsection{Bodemligging/beweging}

Onderstaande figuren geven de hoogte en de migratiesnelheid van de zandgolven weer in het windpark Borssele. De zandgolven binnen het windpark Borssele wisselen in lengte, hoogte en "loopsnelheid". Een zandgolf met een golflengte (top tot top) en een hoogte van 1 meter, heeft een gemiddelde gradiënt van $2 \mathrm{~cm}$ per meter (het hoogte verschil van 1 meter wordt over een afstand van 100 meter 2x overbrugd, van top naar trog en weer naar de top). Als deze golf loopt met een snelheid van 2 meter per jaar komt dat neer op een gemiddelde verandering van bodemhoogte van zo'n $4 \mathrm{~cm}$ per jaar, ofwel $0.011 \mathrm{~cm} /$ dag. De golflengte varieert in Borssele tussen de 114 en de 513 meter (mediane lengte $234 \mathrm{~m}$ ), de hoogte varieert tussen de 1.4 en de 7 meter (mediaan $3.7 \mathrm{~m}$ ) en de loopsnelheid varieert tussen de 0.6 en de 3.2 meter per jaar (mediaan $1.7 \mathrm{~m}$ per jaar).

Gemiddeld is de verandering van hoogte (sedimentatie of erosie) $0.015 \mathrm{~cm}$ per dag (dus $5 \mathrm{~cm}$ per jaar). Maximaal is dit $0.108 \mathrm{~cm} /$ dag (= $40 \mathrm{~cm}$ per jaar) en minimaal op $0.001 \mathrm{~cm} / \mathrm{dag}$. Dit is ruim onder de geschatte tolerantie van de oesters van $0.8 \mathrm{~cm} / \mathrm{dag}$. Als alleen van deze netto, jaargemiddelde grenzen wordt uitgegaan dan zou het hele Borsselepark in principe op het onderwerp bodembeweging als geschikt worden geclassificeerd. Echter, het is belangrijk te bedenken dat bodembeweging vaak niet geleidelijk gaat, maar vooral tijdens korte episodes van storm plaatsvindt. Zeker de meer dynamische gebieden met jaargemiddelde bodemverandering van $0.1 \mathrm{~cm}$ per dag zullen zeer waarschijnlijk een aantal keer per jaar de tolerantiegrenzen overschrijden. Het is op basis van de huidige kennis erg lastig precies te voorspellen in welke gebieden de tolerantiegrenzen niet worden overschreden, maar voor keuzes van locaties binnen het Borsselepark is het zeker zinvol om gebieden met een lage golfmigratiesnelheid te kiezen. Dit zijn de witte gebieden in het onderste figuur. Voor de andere windparken ontbreken gegevens over bodembeweging. Borssele is waarschijnlijk het meest dynamische park, dus de andere parken zijn waarschijnlijk allen geschikt voor platte oesters als het gaat om bodembeweging. 


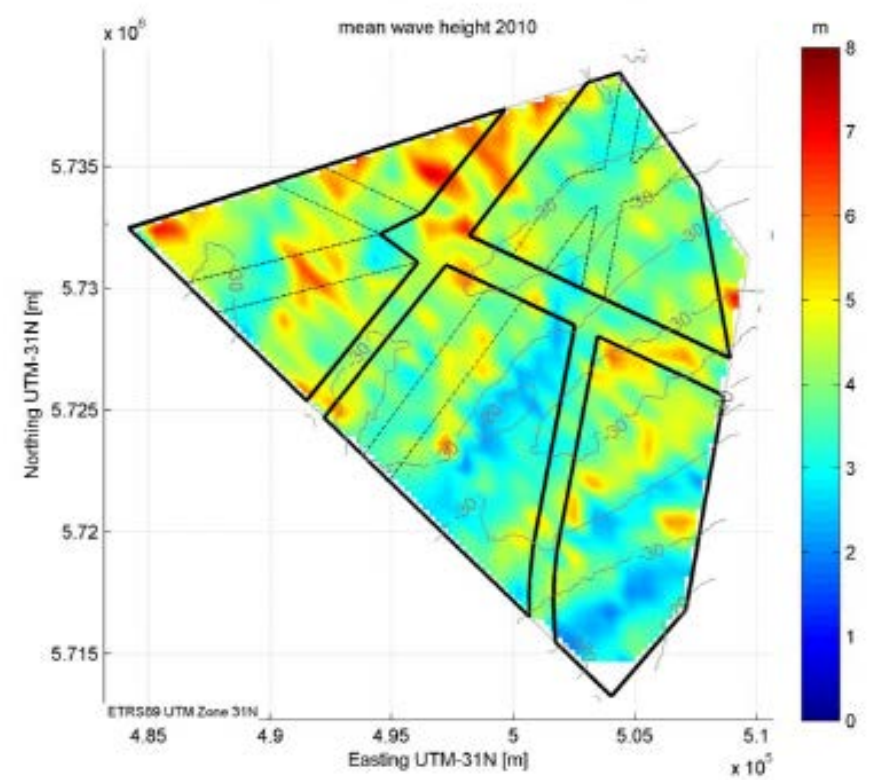

Figure 4.13 Map plots of wave lengths (top plot) and wave heights (bottom plot) estimated using the automatic selection of crest and trough points of 665 transects from the 2010 survey

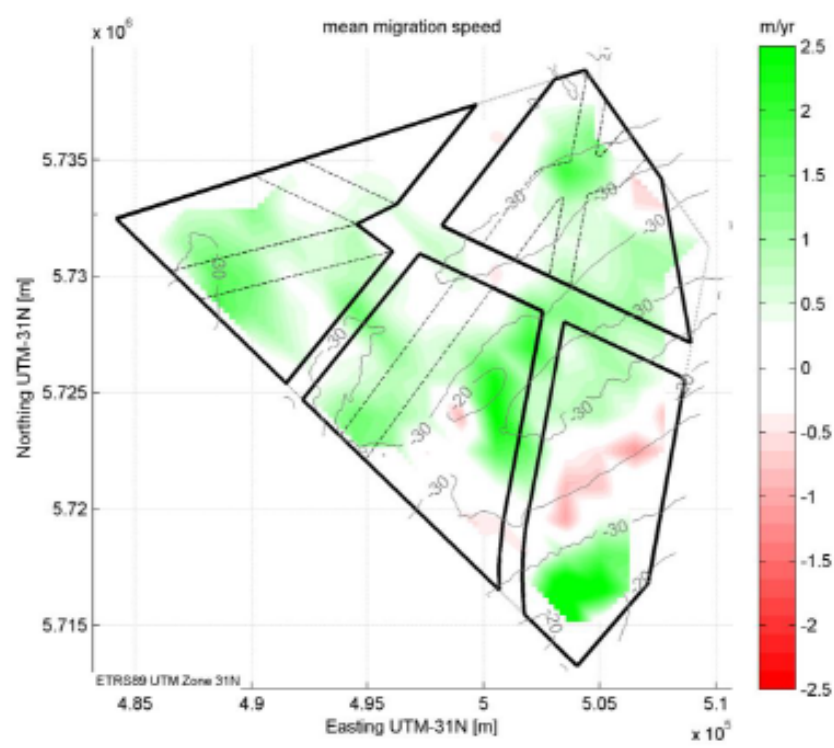

Figure 4.11 Map plots of migration distances (top plot) and migration speeds (bottom plot) estimated using the manual selection of crest and trough points of 153 transects in $B W F Z$ (red $=N E$, green $=S W$ ).

Figuur 4.2.2.1. Zandgolfhoogte (bovenste figuur) en migratiesnelheid in noordoostelijke en zuidoostelijke richting (onderste figuur) in het windpark Borssele. Uit: Riezebos et al 2014. Rechtsboven: kavel I; rechtsonder: kavel II; midden: kavel III; linksboven: kavel IV.

\subsubsection{Zwevendstofgehaltes}

De zwevendstofgehaltes (ook wel aangeduid als slibconcentraties) in de onderste waterlaag zijn aan modelberekeningen ontleend. Dit geldt zowel voor de jaargemiddelde als de extreme zwevendstofgehaltes, zie fig 4.2.3. De kaarten zijn op dezelfde kleurschaal geplot. Ook de locaties waar op dit moment platte oesters worden aangetroffen in de monding van de Grevelingen hebben volgens dit model hoge concentraties (> $50 \mathrm{mg} / \mathrm{l}$ ) zelfs onder 'normale' 
condities. Dit model is echter te grofmazig om zeer lokale condities (b.v. beschutting door de aanwezigheid van een golfbreker of een dam weer te geven, wat daar zal resulteren in lagere zwevendstofgehalte.

Bij de jaargemiddelde condities liggen de grootste concentraties altijd in de ondiepe kustzone, waar slib door de golfwerking veel wordt opgewerveld. Tijdens piekcondities valt op dat er redelijk hoge concentraties worden gemodelleerd ook in de onderste lagen op de oestergronden. Materiaal dat elders wordt opgewerveld tijdens een storm kan juist op deze locaties gaan bezinken. Dit geeft verhoogde concentraties juist op deze locaties.
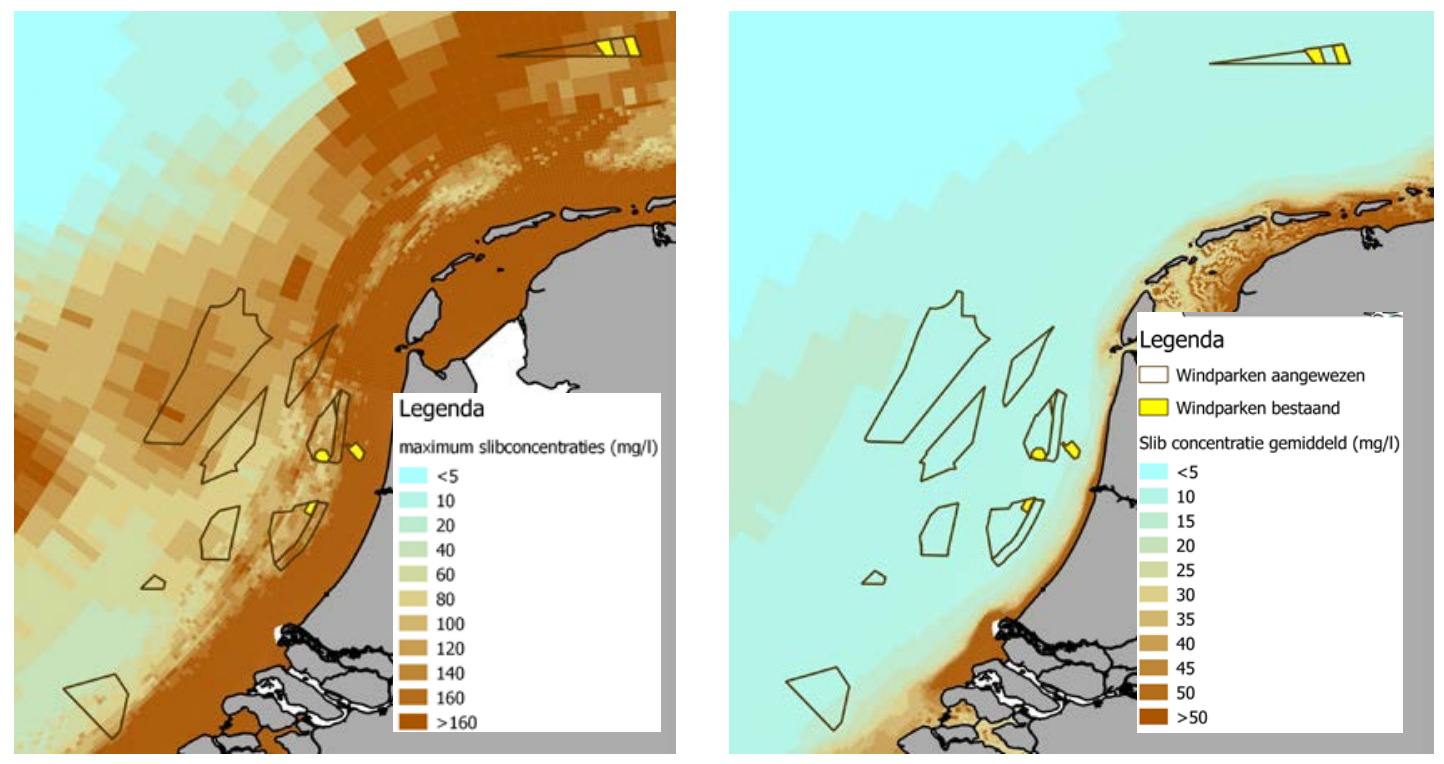

Fig 4.2.3. Maximum- en gemiddelde concentraties anorganisch zwevend stof bij de bodem in de Nederlandse kustzone op basis van modelsimulatie.

\subsection{Geschiktheid windparklocaties voor platte oesters}

Een aantal habitateisen is geselecteerd om de geschiktheid van de onderzochte windparklocaties voor platte oesters te beoordelen. Dit zijn bodemschuifspanning, anorganisch zwevendstofgehaltes, watertemperatuur, bodemligging/beweging en sedimentsamenstelling. Aan deze beoordeling is informatie over de historische verspreiding op basis van Olsen (1883) en Houziaux (2011) toegevoegd, alsmede recente vondsten van losse platte oesters, onder meer op de steenbestorting en funderingspalen in de windparken OWEZ en Prinses Amalia (Bouma \& Lengkeek, 2013; Smaal et al., 2015). De waarden voor de verschillende habitatfactoren zijn vastgesteld op basis van de kaarten in sectie 4.1 en 4.2. De beoordelingen van de verschillende windparklocaties zijn gebaseerd op deze waarden in combinatie met de tolerantiegrenzen van platte oesters zoals bekend in de literatuur (Tabel 4.1.1).

De meest omvangrijke verspreiding van platte oesters in de Noordzee is bekend uit oude publicaties uit tweede helft 19e eeuw (Olsen, 1883) en begin 20e eeuw (geciteerd in Gercken \& Schmidt, 2014; Houziaux 2011). De platte oester is in het Nederlandse deel van de Noordzee recentelijk bekend uit de Voordelta (gemengde populatie platte oester en Japanse oester) en verder uit de Grevelingen en Oosterschelde. De historische verspreiding van platte oesters in het Nederlandse deel van de Noordzee omvatte de monding van het Kanaal tot aan de Vlakte van de 
Raan (nearshore; Houziaux 2011), de Centrale Oestergronden en de zuidrand van de Doggersbank (offshore, Olsen, 1883). Verder kwam de platte oester voor in de sublitorale delen (inshore) van de Noordelijke Zuiderzee (nu Waddenzee) en de voormalige Zuidelijke Zuiderzee ( nu IJ sselmeer, Markermeer en IJ meer). Het voorkomen in de Centrale Oestergronden (het noorden van het NCP) wordt gekenmerkt door een uitgestrekt en continu verspreidingsgebied ver van de kustgebieden. De voorkomens in het Kanaal en tot aan de Vlakte van de Raan (het zuiden van het NCP) zijn kleiner, gefragmenteerd en op relatief regelmatige afstand tot de kust.

Deze drie gebieden (inshore, nearshore en offshore) verschillen aanzienlijk in een aantal abiotische factoren (sedimentsamenstelling, stroomsnelheid, bodemschuifspanning, zwevendstofgehalte, watertemperatuur). Daardoor is het lastig om een eenduidig profiel te extraheren voor het voorkomen van de platte oester. Het is mogelijk dat ongunstige omstandigheden voor één van de levensstadia, gecompenseerd kunnen worden door een andere gunstige factor. Om die reden zal ook de historische verspreiding als aparte factor worden gebruikt om de potentiële geschiktheid van een gebied te evalueren: tabel 4.3.1.

Tabel 4.3.1. Habitatgeschiktheid windparken voor platte oesters op basis van bodemschuifspanning, zwevend stof, watertemperatuur (winter-minimum en zomer-maximum), bodemligging/beweging, sedimentsamenstelling en historische verspreiding: wit minder geschikt, rood $=$ matig geschikt, groen $=$ geschikt .

\begin{tabular}{|c|c|c|c|c|c|c|c|c|c|c|}
\hline \multirow[t]{2}{*}{ windpark } & \multicolumn{3}{|c|}{ bodemschuifspanning Tau N/m2 } & \multicolumn{2}{|c|}{$\begin{array}{l}\text { zwevend stof } \\
(\mathrm{mg} / \mathrm{l})\end{array}$} & \multicolumn{2}{|c|}{ watertemp oC } & \multirow{2}{*}{\begin{tabular}{|l} 
bodem \\
ligging / \\
beweging \\
$\mathrm{cm} / \mathrm{dag}$
\end{tabular}} & \multirow[t]{2}{*}{$\begin{array}{l}\text { sediment } \\
\text { samenstelling }\end{array}$} & \multirow[t]{2}{*}{$\begin{array}{l}\text { historische } \\
\text { verspreiding }\end{array}$} \\
\hline & $\max$ & \begin{tabular}{|l|}
$\max$ \\
golf \\
werking \\
\end{tabular} & gem & $\max$ & gem & $\min$ & $\max$ & & & \\
\hline Borssele & 2 & 2 & 0,6 & 25 & 10 & 4 & 20 & 0 (lokaal) & $\begin{array}{l}\text { grof tot fijn } \\
\text { zand }\end{array}$ & ja \\
\hline OWEZ & 8 & 8 & 0,8 & 50 & 20 & 3 & 20 & $?$ & fijn zand & nee \\
\hline HK-noord & 5 & 6 & 0,6 & 35 & 10 & 4 & 18 & $?$ & fijn zand & nee \\
\hline Luchterduinen & 5 & 6 & 0,6 & 35 & 10 & 3 & 20 & $?$ & fijn zand & nee \\
\hline Prinses Amalia & 5 & 7 & 0,6 & 35 & 10 & 3 & 18 & $?$ & fijn zand & nee \\
\hline
\end{tabular}

De gemiddelde bodemschuifspanning $\left(T_{\mathbf{g e m}}\right)$ in de Gemini-locaties Buitengaats en Zee-energie is geschikt, op de andere locaties matig geschikt (zie 4.2.1). De maximale bodemschuifspanning in totaal en alleen voor de golfwerking zijn het laagst in Borssele en wat hoger op de andere locaties. Wat betreft zwevend stof (gemiddeld en maximaal) zijn alle locaties geschikt voor met uitzondering van OWEZ (zie 4.2.3). Zoals te verwachten zijn de minimale en maximale watertemperatuur bij de bodem wat hoger op de zuidelijke locaties (Borssele tot Luchterduinen) en wat lager op de noordelijke locaties (Gemini Buitengaats en Zee-energie). Op alle locaties is de watertemperatuur geschikt voor platte oesters. Alleen van Borssele is in detail bekend wat de bodembeweging is binnen de locaties wat betreft de hoogte van de zandgolven en de verplaatsingssnelheid (zie 4.2.2). Binnen de kavels zijn voldoende gebieden te vinden waar de bodembeweging afwezig of heel gering is. Het is mogelijk dat de bodemschuifspanning in de dalen van de zandgolven geringer is dan gemiddeld vastgesteld op een grotere schaal. Slibrijk zand, dat beoordeeld wordt als geschikt voor platte oesters, komt alleen voor in de noordelijke windparklocaties en vooral in Gemini Buitengaats. De bodem op andere windparklocaties bestaat voornamelijk uit fijn zand, dat matig geschikt is voor platte oesters. Zoals in sectie 4.1 is 
opgemerkt, bepaalt vooral de hoeveelheid schelpmateriaal op de bodem het potentieel voor de vestiging van oesterlarven, maar daar zijn geen gegevens van voorhanden. In de 19e eeuw kwamen platte oesterbanken algemeen voor in de Noordzee ten noorden van de Waddeneilanden, waaronder ook op de Gemini-locaties (Olsen, 1883). Daarnaast is het voorkomen van platte-oesterbanken in het verleden ook bekend van de locatie Borssele (Houziaux, 2011).

Uit deze habitatgeschiktheidsanalyse blijkt dat alle windparklocaties ten minste matig geschikt zijn voor platte oesters en dat Borssele, Gemini Buitengaats en Gemini Zee-energie geschikt zijn voor platte oesters. Dit hangt vooral samen met de lage gemiddelde (Gemini) en lage maximale (Borssele) bodemschuifspanning en lage bodemdynamiek (Borssele) en het geschikte sediment (slibrijk zand) in Gemini Zee-energie. Recente vondsten van losse platte oesters nabij Borssele, en in OWEZ en Amalia (Smaal et al., 2015) bevestigen dat de meeste windparklocaties geschikt zijn voor de overleving, groei en voortplanting van platte oesters. De historische waarnemingen van het voorkomen van platte-oesterbanken in Borssele en Gemini geven aan dat de ontwikkeling van platte-oesterbanken op deze locaties kansrijk is onder voorwaarde dat er een bron is van larven en voldoende aanbod van geschikt substraat voor vestiging (schelpen): tabel 4.3.2.

Tabel 4.3.2.. Habitatgeschiktheid van de windparklocaties. Voor iedere factor is de relatieve geschiktheid gegeven ( 0 - ongeschikt; 1 - matig geschikt; 2 - geschikt; - geen beoordeling mogelijk) op basis van de tolerantiegrenzen in tabel 4.1.1.

\begin{tabular}{|c|c|c|c|c|c|c|c|}
\hline \multirow[t]{2}{*}{ windpark } & \multirow{2}{*}{\begin{tabular}{|l}
$\begin{array}{l}\text { bodem } \\
\text { schuifspanning }\end{array}$ \\
gem
\end{tabular}} & \multicolumn{2}{|c|}{ zwevend stof } & \multicolumn{2}{|l|}{ watertemp } & \multirow{2}{*}{$\begin{array}{l}\text { sediment } \\
\text { samenstelling }\end{array}$} & \multirow{2}{*}{$\begin{array}{l}\text { historische } \\
\text { verspreiding }\end{array}$} \\
\hline & & $\max$ & gem & $\min$ & $\max$ & & \\
\hline Borssele & 1 & 2 & 2 & 2 & 2 & 1 & 2 \\
\hline HK-Zuid & 1 & 2 & 2 & 2 & 2 & 1 & 1 \\
\hline OWEZ & 1 & 1 & 2 & 2 & 2 & 1 & 1 \\
\hline HK-noord & 1 & 2 & 2 & 2 & 2 & 1 & 1 \\
\hline Luchterduinen & 1 & 2 & 2 & 2 & 2 & 1 & 1 \\
\hline Prinses Amalia & 1 & 2 & 2 & 2 & 2 & 1 & 1 \\
\hline Buitengaats & 2 & 2 & 2 & 2 & 2 & 1 & 2 \\
\hline Zee-energie & 2 & 2 & 2 & 2 & 2 & 2 & 2 \\
\hline
\end{tabular}

\subsection{Larventransport}

In onderstaande figuren is de gesimuleerde larvenverspreiding weergegeven met de verschillende parken als bron. De figuren geven de gemiddelde concentratie per $\mathrm{m}^{2}$ bij de bodem weer van deeltjes die 10 dagen oud zijn, uitgaande van een totaal vrijkomende hoeveelheid van $1.26 \times 10^{8}$ (arbitraire eenheden). De kaartjes geven dus een relatief beeld van de verspreiding. De verspreidingskaartjes (van donkergroen naar geel: afnemende larvenconcentratie) laten zien dat in de parken Borssele (Fig 4.4.1a) en de twee noordelijke parken Buitengaats en Zee-energie (Fig 4.4.1 g en h) de retentie van larven duidelijk hoger is dan in de andere parken langs de Hollandse kust. Die parken liggen onder invloed van de uitstroom van de Rijn met als gevolg een noordwaarts gerichte stroming. In Borssele- en de Gemini-parken staat wel getijstroming, maar hier is de netto-stroming relatief klein. Dat betekent dat voor de parken langs de Hollandse kust 
de meeste larven van 10 dagen oud het park verlaten. Vanuit deze parken kunnen wel relatief gemakkelijk naburige parken worden bereikt. Een populatie die zich binnen deze parken bevindt is waarschijnlijk voor een belangrijk deel afhankelijk van aanvoer van larven van elders.

Uiteraard is deze modelsimulatie en de conclusies die er uit getrokken worden gevoelig voor de aannames die gedaan worden t.a.v. de duur van de larvale fase (een planktonische levensfase van 10 dagen) en t.a.v. de wijze van voortbeweging van de larven (passief). Het is goed mogelijk dat in het veld bij de heersende temperaturen in het paaiseizoen, de planktonische periode wat langer is en dat de larven tevens actieve beweging laten zien. Het algemene patroon zal niettemin blijven zoals het is, maar gemiddeld zal ook de populatiedichtheid van de larven toenemen hetgeen de kansen van vestiging verhoogt. De maximale afstand die de larven kunnen afleggen zal ook groter worden.

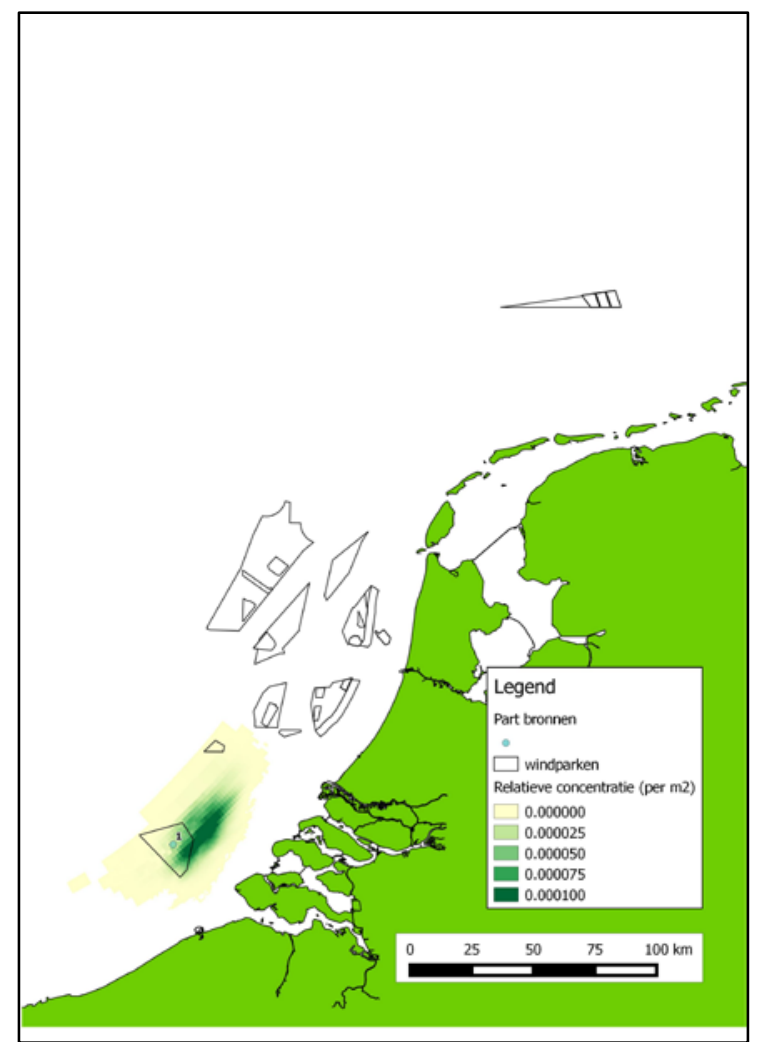

Figuur 4.4.1a Gesimuleerde larvenverspreiding gedurende 10 dagen vanuit windpark Borssele. De concentraties in de legenda zijn relatieve waarden; de figuur geeft dus de verspreiding aan en niet de absolute concentraties. 


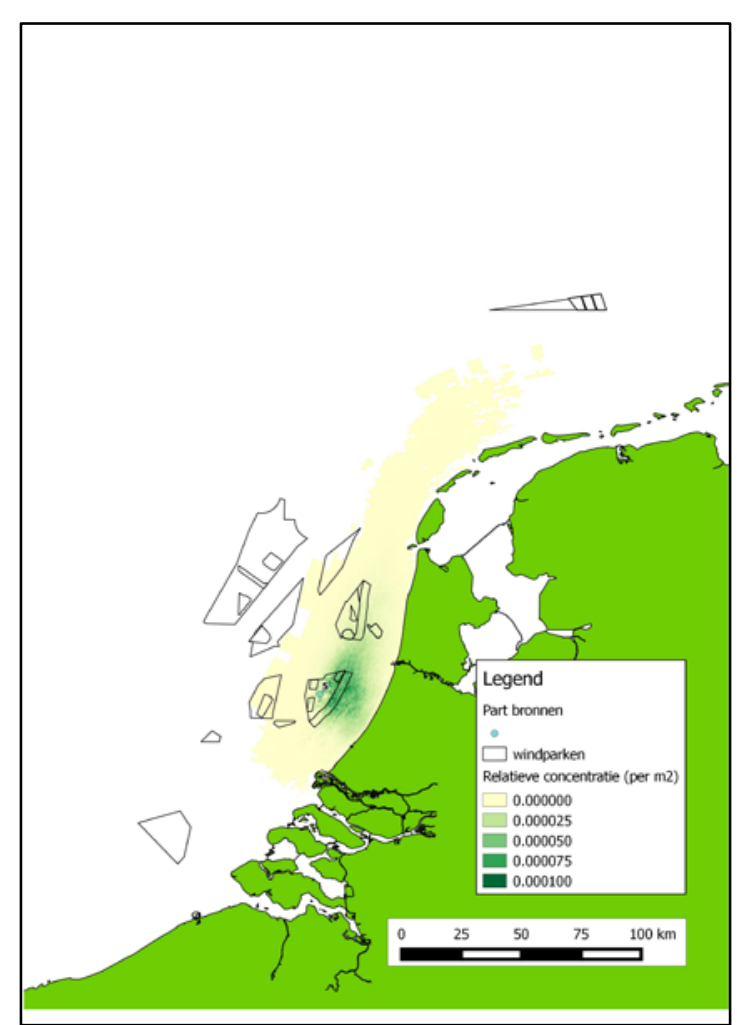

Figuur 4.4.1b Idem HK-zuid.

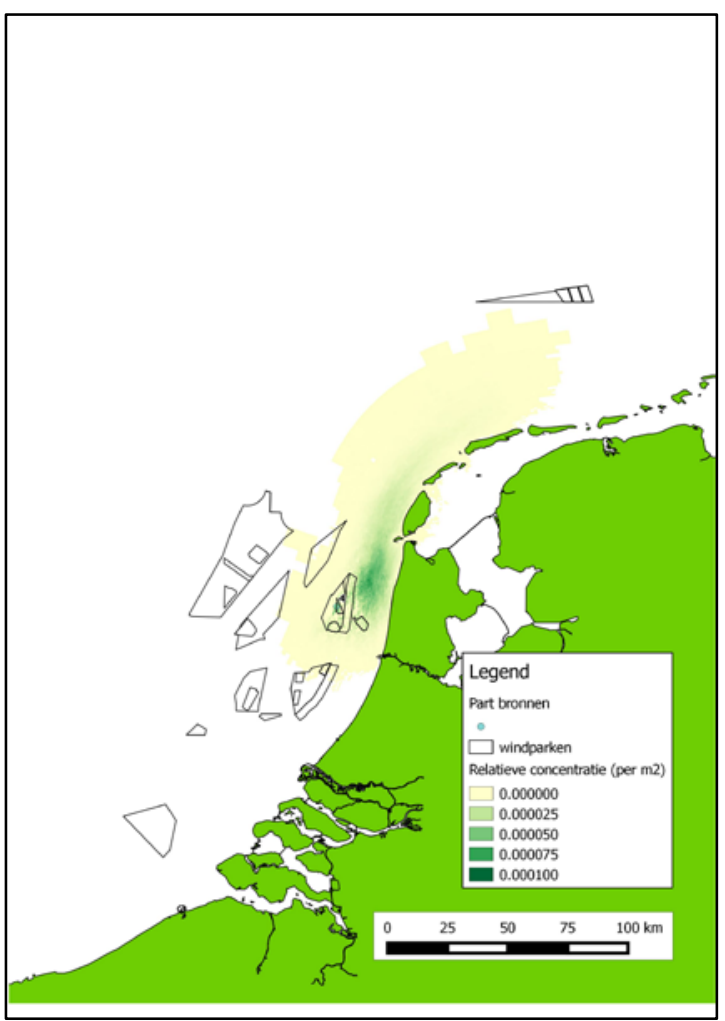

Figuur 4.4.1d Idem HK-noord.

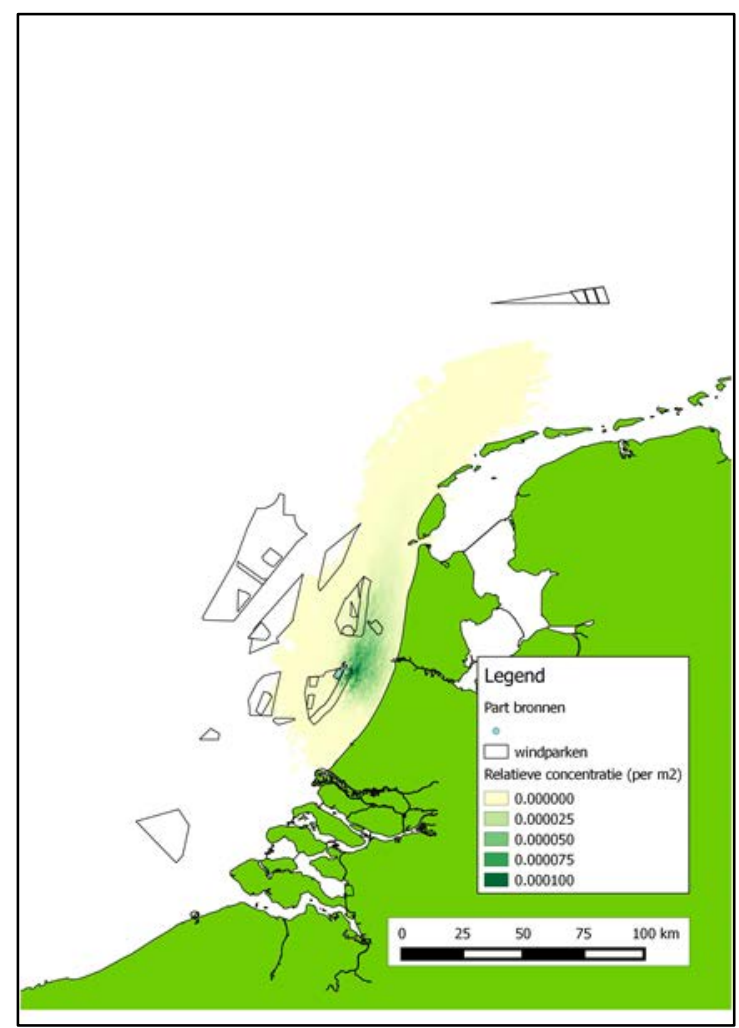

Figuur 4.4.1c idem Luchterduinen.

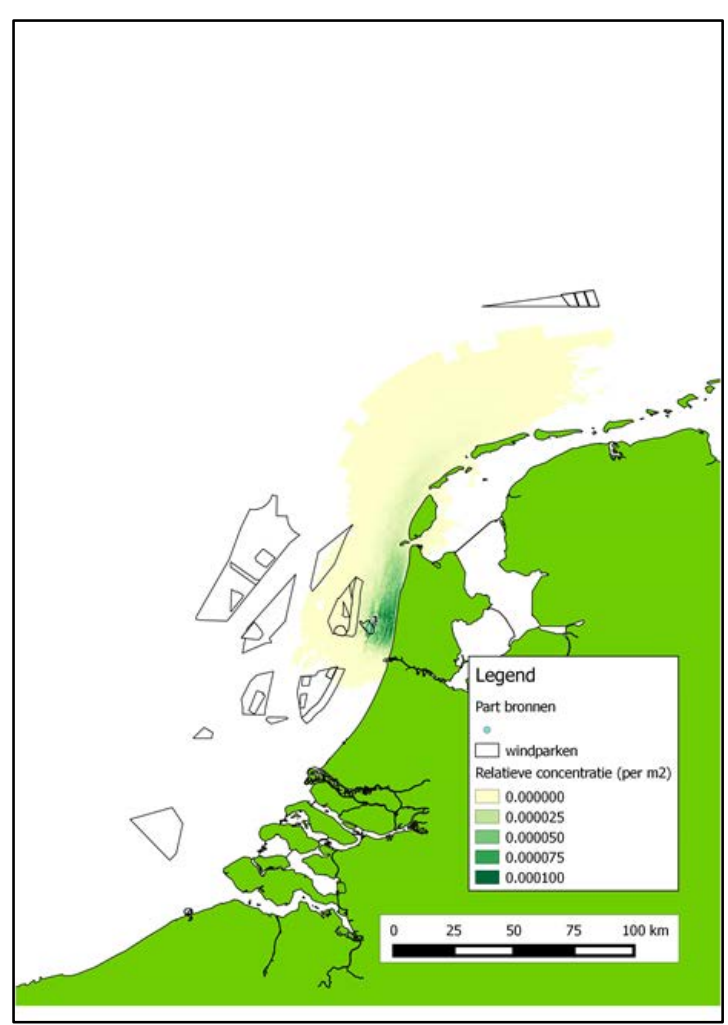

Figuur 4.4.1 ${ }^{\mathrm{e}}$ I dem OWEZ. 


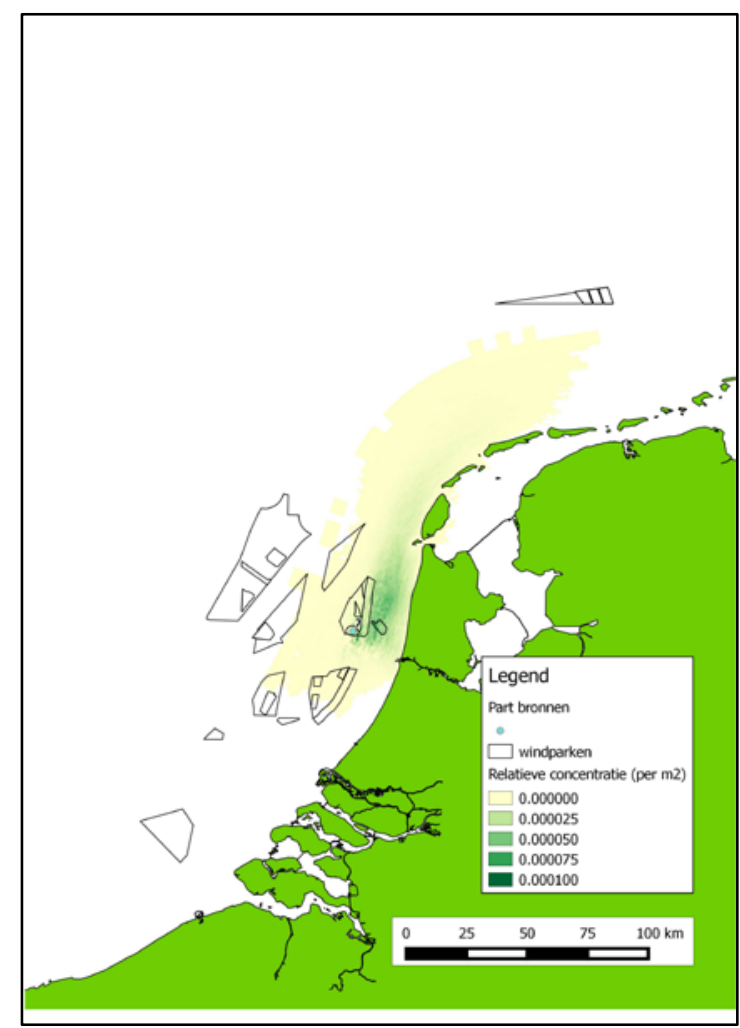

Figuur 4.4.1f Idem Prinses Amalia.

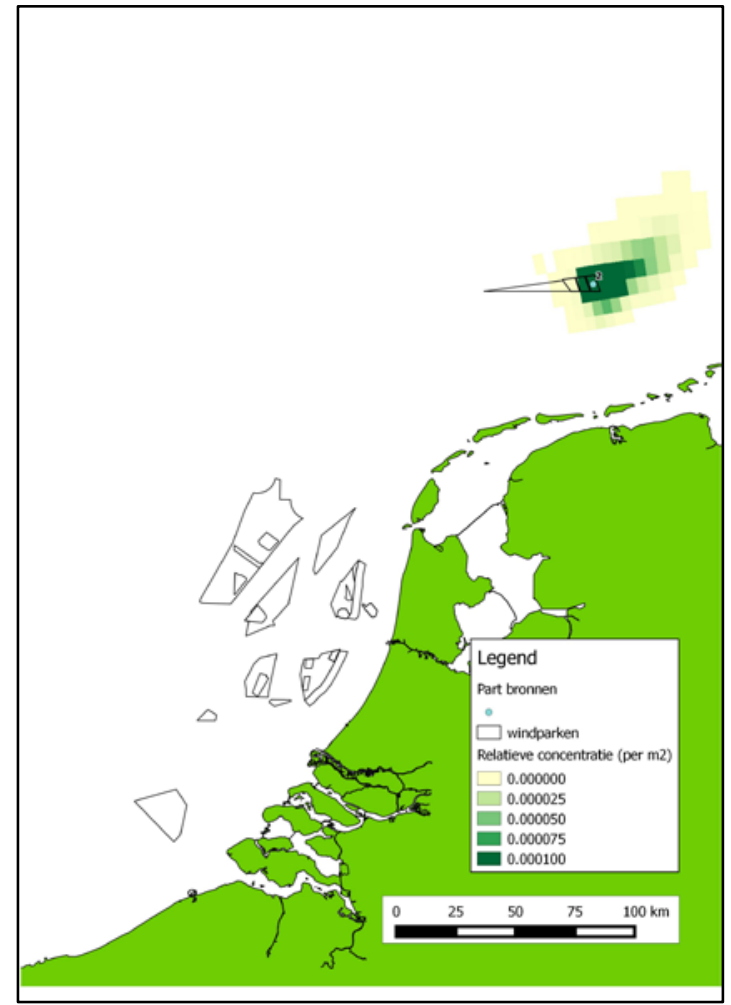

Fuguur 4.4.1g Idem Buitengaats.

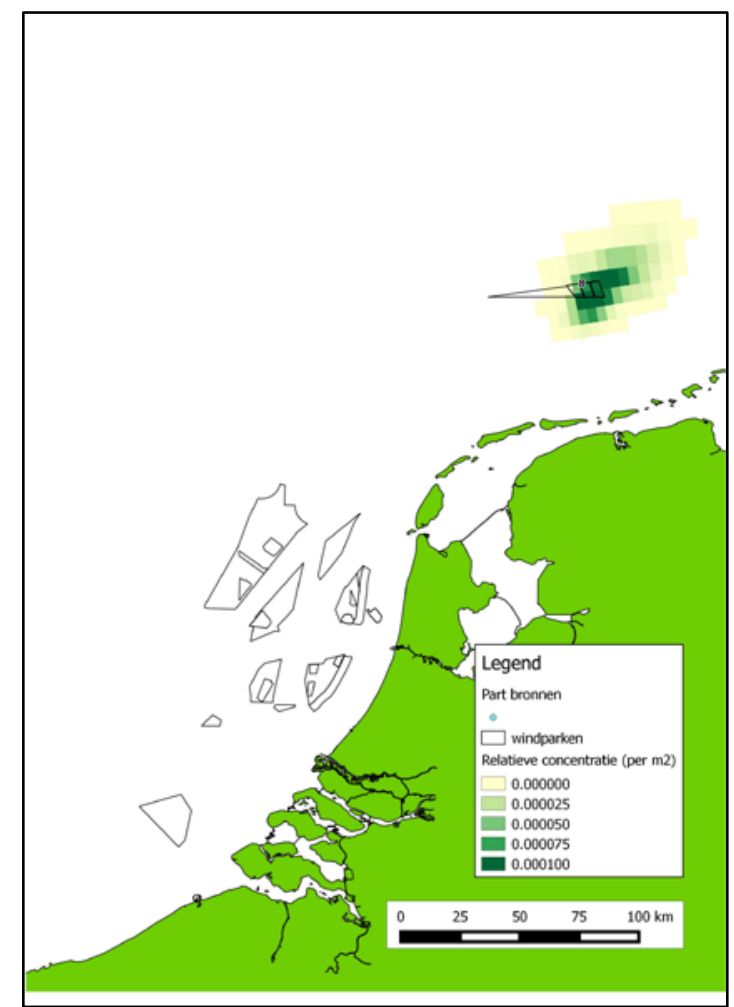

Figuur 4.4.1h Idem Zee-energie.

In tabel 4.4.1 is weergegeven in hoeverre larven vanuit een bepaald park voornamelijk in hetzelfde park terecht komen (groen) of ook andere parken bereiken (blauw). In de huidige simulatie lijken larven vanuit Borssele de andere locaties net niet te kunnen bereiken. Bij een iets langere planktonische fase zal Borssele eventueel wel als bronlocatie kunnen dienen. Larven uit Kust-zuid bereiken ook Luchterduinen, OWEZ en Amalia. Vanuit Luchterduinen is er toevoer naar Owez en 
Amalia. Larven uit het Amaliapark verplaatsen zich richting OWEZ en leiden niet tot broedval in het Amaliapark zelf. Voor Zee-energie geldt dat deze ook Buitengaats bereikt, terwijl de larven vanuit Buitengaats in oostelijke richting uitspoelen.

Tabel 4.4.1. Indicatie larventransport binnen (groen) en tussen (blauw) windparklocaties in het NCP.

\begin{tabular}{|l|l|l|l|l|l|l|l|l|}
\hline & Bron & & & & & & & \\
\hline Station & Borssele & Kust Z & $\begin{array}{l}\text { Luchter } \\
\text { duinen }\end{array}$ & Owez & Amalia & Kust N & $\begin{array}{l}\text { Zee- } \\
\text { energie }\end{array}$ & $\begin{array}{l}\text { Buiten } \\
\text { gaats }\end{array}$ \\
\hline Borssele & & - & - & - & - & - & - & - \\
\hline Kust-Z & - & & - & - & - & - & - & - \\
\hline Luchterduinen & - & & & - & - & - & - & - \\
\hline Owez & - & & & & & & & - \\
\hline Amalia & - & & & - & - & & - & - \\
\hline Kust-N & - & - & - & - & - & & - & - \\
\hline Zee-energie & - & - & - & - & - & - & & - \\
\hline Buitengaats & - & - & - & - & - & - & & \\
\hline
\end{tabular}

\subsection{Kritische massa}

Met het model is berekend hoeveel oesters er in een gebied nodig zijn om ervoor te zorgen dat er voldoende larven worden geproduceerd voor een concentratie van 50 per $\mathrm{m}^{2}$, die als minimum wordt gezien voor rekrutering. Daarbij is de berekening niet alleen gedaan voor het brongebied zelf maar is ook nagegaan in hoeverre de bron bij een bepaalde hoeveelheid oesters zoveel larven produceert dat ook andere windparken "bevrucht" kunnen worden. In een aantal gevallen blijkt dit inderdaad mogelijk te zijn, en is er dus rekrutering mogelijk van larven uit een ander park.

De modelsimulatie geeft kwalitatieve indicaties; kwantificering vereist betere onderbouwing van de aannames in het model. Daarom is onderscheid gemaakt in 5 categorieën A-E, met bij A relatief weinig oesters nodig om voldoende larven voor rekrutering over te houden en bij $E$ heel veel. De kwalitatieve indicaties weergegeven in tabel 4.5.1 laten zien dat er relatief weinig oesters nodig zijn in het noordelijk gelegen Zee-energiepark, met name voor rekrutering in gebied Buitengaats (categorie A en B). Verder blijkt uit tabel 4.5.1. dat Hollandse Kust Zuid zorgt voor rekrutering in Luchterduinen en Amalia voor park OWEZ, en dat daar een relatief beperkt areaal oesters voor nodig is. Deze zijn blauw gescoord omdat er dus geen goede rekrutering plaats vindt in het brongebied zelf. Voor rekrutering in Luchterduinen is een groter aantal oesters nodig; dit geldt ook voor Borssele (categorie C). Voor rekrutering vanuit Hollandse Kust Noord zijn relatief veel oesters nodig, omdat het grootste deel van de larven wegspoelt, tot in de Waddenzee. 
Tabel 4.5.1. Relatieve omvang van het bestand aan oesters dat nodig is voor rekrutering in hetzelfde of nabij gelegen gebied. Cat $A=$ minimum, Cat $E=$ maximum stock benodigd. Met de kleur groen is aangegeven dat er rekrutering in het park zelf plaats vindt, met blauw is dat niet het geval; rood geeft aan dat er minder rekrutering plaats vindt in de parken.

\begin{tabular}{|l|l|l|l|l|l|l|l|l|}
\hline & Bron & & & & & & & \\
\hline Station & Borssele & Kust Z & $\begin{array}{l}\text { Luchter } \\
\text { duinen }\end{array}$ & Owez & Amalia & Kust N & $\begin{array}{l}\text { Zee- } \\
\text { energie }\end{array}$ & $\begin{array}{l}\text { Buiten } \\
\text { gaats }\end{array}$ \\
\hline Borssele & C & - & - & - & - & - & - & - \\
\hline Kust-Z & - & D & - & - & - & - & - & - \\
\hline Luchterduinen & - & B & C & - & - & - & - & - \\
\hline Owez & - & E & D & C & B & E & - & - \\
\hline Amalia & - & E & E & - & - & E & - & - \\
\hline Kust-N & - & - & - & - & - & E & - & - \\
\hline Zee-energie & - & - & - & - & - & - & B & - \\
\hline Buitengaats & - & - & - & - & - & - & A & D \\
\hline
\end{tabular}




\subsection{Integratie}

Voor de ontwikkeling van oesterbanken in de Noordzee moeten de omstandigheden voldoen aan de eisen voor de hele levenscyclus van overleving, groei, voortplanting en succesvolle rekrutering. Overleving is vooral bepaald door de grootschalige ne kleinschalige bodemdynamiek, respectievelijk vertaald naar bodembeweging en bodemschuifspanning. Voor bodembeweging is nagegaan wat de situatie is voor locatie Borssele waarvan bekend is dat deze relatief veel zandgolven kent in vergelijking met de andere parken. Het blijkt dat de bodembeweging aldaar niet op alle locaties beperkend voor oesters, dus grootschalige bodemdynamiek op zich is geen beperking. Wel is de bodemschuifspanning verschillend tussen de locaties; de laagste waarden komen voor in het Gemini gebied, de parken Zee-energie en Buitengaats. Bodemschuifspanning correspondeert voor de meeste parken met sedimentsamenstelling; de bodem van Zee-energie bevat wat meer slib. Wat betreft overleving is de score dus het hoogst voor Zee-energie, Buitengaats en Borssele. Dit zijn ook de locaties die relatief dicht gelegen zijn bij locaties waar in het verleden platte oesters zijn waargenomen. De kustlocaties scoren dus lager wat betreft bodemschuifspanning, sedimentsamenstelling en historisch voorkomen. Factoren als zuurstofgehalte en saliniteit zijn niet beperkend voor de overleving van oesters in de parken. Groei en voortplanting hangen vooral af van de voedselbeschikbaarheid en die wordt bepaald door fytoplankton en zwevend stof. Zwevend stof is een remmende factor en fytoplankton wordt niet als beperkend beschouwd. Daarom is nagegaan in hoeverre het zwevendstofgehalte bij de bodem verschilt tussen de parken en beperkend is. Dit is in feite alleen bij OWEZ het geval, de locatie die het meest dicht bij de kust ligt. De watertemperatuur is geen belemmering voor de voortplanting, mede gezien de gegevens over de historische voorkomens van platte oesters in de Noordzee. Wat betreft kans op vestiging blijkt uit de modelsimulaties dat in Buitengaats succesvolle rekrutering kan optreden, met name vanuit een relatief kleine ouderpopulaties van Zee-energie. De nabijheid en de reststroom in oostelijke richting dragen hieraan bij. Verder blijkt uit de simulaties dat park Prinses Amalia zal kunnen fungeren als bron voor larven die in OWEZ settelen. Park Borssele heeft met een middelmatige bestandsomvang kans op succesvolle rekrutering binnen het park, en dit geldt ook voor Luchterduinen.

Voor de gehele levenscyclus zouden dus de locaties Zee-energie in combinatie met Buitengaats relatief geschikt zijn voor de ontwikkeling van platte-oesterbanken, gevolgd door Borssele en Luchterduinen. In de ondiepere kustlocaties zijn er ook mogelijkheden voor oesterbanken maar daar is de bodem net wat minder stabiel en is er meer uitspoeling van larven, die niet direct ten goede komen aan nabij gelegen parken.

Tabel 4.6.1. Overzicht van de relatieve geschiktheid (ongewogen) van de windparken voor de ontwikkeling van platte-oesterbanken.

\begin{tabular}{|c|c|c|c|c|c|c|c|c|c|}
\hline \multirow[t]{2}{*}{ windpark } & \multirow{2}{*}{\begin{tabular}{|l}
$\begin{array}{l}\text { bodem } \\
\text { schuif } \\
\text { spanning }\end{array}$ \\
gem
\end{tabular}} & \multicolumn{2}{|c|}{ zwevend stof } & \multicolumn{2}{|c|}{$\begin{array}{l}\text { water } \\
\text { temperatuur }\end{array}$} & \multirow[t]{2}{*}{ sediment } & \multirow[t]{2}{*}{\begin{tabular}{|l|} 
historische \\
verspreiding
\end{tabular}} & \multirow[t]{2}{*}{$\begin{array}{l}\text { larven } \\
\text { aanbod }\end{array}$} & \multirow[t]{2}{*}{ som } \\
\hline & & $\max$ & gem & $\min$ & $\max$ & & & & \\
\hline Borssele & 1 & 2 & 2 & 2 & 2 & 1 & 2 & 2 & 14 \\
\hline HK-Zuid & 1 & 2 & 2 & 2 & 2 & 1 & 1 & 1 & 12 \\
\hline OWEZ & 1 & 1 & 2 & 2 & 2 & 1 & 1 & 2 & 12 \\
\hline HK-noord & 1 & 2 & 2 & 2 & 2 & 1 & 1 & 1 & 12 \\
\hline Luchterduinen & 1 & 2 & 2 & 2 & 2 & 1 & 1 & 2 & 13 \\
\hline Prinses Amalia & 1 & 2 & 2 & 2 & 2 & 1 & 1 & 1 & 12 \\
\hline Buitengaats & 2 & 2 & 2 & 2 & 2 & 1 & 2 & 1 & 14 \\
\hline Zee-energie & 2 & 2 & 2 & 2 & 2 & 2 & 2 & 2 & 16 \\
\hline
\end{tabular}




\section{Conclusies}

De conclusies uit deze studie naar mogelijkheden voor overleving, groei, reproductie en rekrutering van platte-oesterpopulaties (Ostrea edulis) binnen bestaande en geplande windmolenparken in het Nederlandse deel van de Noordzee, luiden als volgt:

1. Belangrijke habitatfactoren voor de ontwikkeling van platte-oesterbanken in de windparken in het Nederlandse deel van de Noordzee zijn (i) grootschalige en kleinschalige bodemdynamiek, (ii) sedimentsamenstelling, (iii) zwevendstofgehalte in de waterkolom en (iv) de mogelijkheid voor succesvolle rekrutering. Dit laatste hangt af van de omvang van de ouderpopulatie en de waterbeweging.

2. Andere factoren zoals fytoplankton-, zout- en zuurstofgehalte zijn ook belangrijk maar die zijn niet beperkend; predatie en competitie zijn eveneens van belang maar daarvan is niet aan te geven in hoeverre dit beperkingen oplegt aan de ontwikkeling van platteoesterbanken in de windparken.

3. De relatieve geschiktheid van de windparken voor de platte oester is in deze analyse bepaald door de bodemschuifspanning (kleinschalige bodemdynamiek) en daarmee samenhangend de sedimentsamenstelling, het zwevendstofgehalte en de kans op rekrutering. Zandgolfmigratie (grootschalige bodemdynamiek) is beperkend in een deel van het Borssele-gebied - maar niet overal -, in de andere parken spelen deze geen rol. $\mathrm{Er}$ is verder ook gekeken naar gegevens over het voorkomen van oesterbanken in het (verre) verleden, als een kwalitatieve ijking van de habitatgeschiktheid.

4. Uit bovengenoemde analyse blijkt dat de locaties Zee-energie in combinatie met Buitengaats relatief geschikt zijn voor de ontwikkeling van oesterbanken; ook Borssele wordt geschikt geacht, gevolgd door Luchterduinen. Deze laatste locatie is interessant voor een pilot omdat deze al in bedrijf is, en qua logistiek gunstig gelegen is. In de ondiepere kustlocaties zijn er ook mogelijkheden voor platte-oesterbanken maar daar is de bodem net wat minder stabiel en is er meer uitspoeling van larven, die niet direct ten goede komen aan nabij gelegen parken.

5. Gezien de aannames en onzekerheden is empirische toetsing van de conclusies via pilotstudies en experimenten een noodzakelijke stap in de verdere ontwikkeling van platteoesterbanken in de Noordzee-windparken. 


\section{Aanbevelingen voor een pilot}

Gezien de habitatkarakteristieken van een aantal windparken in de Nederlandse Noordzee zijn er in principe mogelijkheden voor de ontwikkeling van platte-oesterbanken in geselecteerde parken. Er zijn evenwel onzekerheden in de habitatanalyse over de combinatie van omgevingsfactoren en de rol van predatoren. Verder zijn er diverse aannames gedaan in de berekening van de kritische massa die nodig is voor een zichzelf in stand houdende oesterpopulatie.

De onzekerheden kunnen worden gereduceerd door met behulp van pilots in het veld uit te zoeken welke factoren er daadwerkelijk toe doen. In de pilots kunnen ook aannames voor de modelberekening empirisch worden ingevuld. Op basis van de ervaringen van de pilots in de Voordelta (Sas et al, 2016) en op basis van experimenten elders (zu Ermgassen et al, 2016) kan een pilot voor Noordzeewindparken worden opgezet.

Als doelstelling van een dergelijke pilot kan dan gelden: in de praktijk uittesten (1) in hoeverre de platte oesters op de gekozen locatie kunnen overleven, groeien en reproduceren, (2) of de oesterbank zichzelf in stand kan houden via rekrutering (larvenproductie en aanbod substraat voor vestiging), en (3) in hoeverre de oesterbank een habitat vormt voor andere soorten. De aanpak kan op hoofdlijnen bestaan uit: (1) het creëren van een bron van larven en (2) het aanbieden van geschikt substraat. Een larvenbron kan gegenereerd worden door het uitzetten van een minimum areaal aan platte oesters van verschillende leeftijd (cq grootte), waarvan een deel wordt beschermd tegen predatie. De ontwikkeling van de oesters zal in de groei- en paaiperiode moeten worden gemonitord wat betreft overleving, groei en gonadenontwikkeling. In de paaiperiode kunnen er watermonsters worden genomen voor de larventellingen. Met behulp van broedcollectoren kan vestiging van larven worden gemonitord. Geschikt substraat voor de vestiging van platte-oesterlarven kan worden aangeboden door het storten van schoon schelpmateriaal (mossels, oesters).

Gezien het feit dat Luchterduinen als relatief kansrijk is beoordeeld, reeds enkele jaren in bedrijf is en het park relatief goed bereikbaar is, kan worden overwogen de pilot daar uit te voeren. $\mathrm{Er}$ zijn evenwel ook andere opties denkbaar voor zover bodemberoering kan worden uitgesloten.

Voor de pilot zal een plan van aanpak kunnen worden opgesteld, en daartoe verdient het de aanbeveling eerst de volgende vragen te beantwoorden:

\section{1 - Locatiekeuze}

= wat zijn de specifieke habitatkarakteristieken van de locatie?

$=$ kan er toestemming worden verkregen voor een pilot?

= wat zijn de logistieke randvoorwaarden en synergiën?

$=$ in hoeverre kan gebruik gemaakt worden van lopende onderzoek-, monitoring en eventuele natuurherstelprogramma's?

$=$ in hoeverre zijn er andere gebruikers actief die mogelijk invloed kunnen hebben op de pilot? 
2 - Randvoorwaarden voor de uitvoering

$=$ kan er van bestaand substraat gebruik gemaakt worden of dient er substraat te worden aangebracht?

$=$ op welke tijd- en ruimteschaal kan de pilot worden uitgevoerd?

$=$ is er risico op omvangrijke predatie en kan dit worden voorkomen?

3 - Uitgangsmateriaal

= welke omvang heeft de startpopulatie?

$=$ in hoeverre dient de uitgangspopulatie Bonamia-vrij te zijn?

= uit welke bronnen kan de startpopulatie worden betrokken?

Voor de uitvoering van de pilot kan een structuur worden aanbevolen met opdrachtgever(s), onderzoekers, ondersteuning, financiering, wetenschappelijke begeleiding en betrokkenheid van stakeholders. 


\section{Kwaliteitsborging}

Wageningen Marine Research beschikt over een ISO 9001:2008 gecertificeerd kwaliteitsmanagementsysteem (certificaatnummer: 187378-2015-AQ-NLD-RvA). Dit certificaat is geldig tot 15 september 2018. De organisatie is gecertificeerd sinds 27 februari 2001. De certificering is uitgevoerd door DNV Certification B.V.

Het chemisch laboratorium te IJ muiden beschikt over een NEN-EN-ISO/IEC 17025:2005 accreditatie voor testlaboratoria met nummer L097. Deze accreditatie is geldig tot 1 april 2021 en is voor het eerst verleend op 27 maart 1997; deze accreditatie is verleend door de Raad voor Accreditatie. Het chemisch laboratorium heeft hierdoor aangetoond in staat te zijn op technisch bekwame wijze valide resultaten te leveren en te werken volgens de ISO17025 norm. De scope (L097) met de geaccrediteerde analysemethoden is te vinden op de website van de Raad voor Accreditatie (www.rva.nl).

Op grond van deze accreditatie is het kwaliteitskenmerk $\mathrm{Q}$ toegekend aan de resultaten van die componenten die op de scope staan vermeld, mits aan alle kwaliteitseisen is voldaan.. Het kwaliteitskenmerk Q staat vermeld in de tabellen met de onderzoeksresultaten. Indien het kwaliteitskenmerk $\mathrm{Q}$ niet staat vermeld is de reden hiervan vermeld.

De kwaliteit van de analysemethoden wordt op verschillende manieren gewaarborgd. De juistheid van de analysemethoden wordt regelmatig getoetst door deelname aan ringonderzoeken waaronder die georganiseerd door QUASIMEME. Indien geen ringonderzoek voorhanden is, wordt een tweede lijnscontrole uitgevoerd. Tevens wordt bij iedere meetserie een eerstelijnscontrole uitgevoerd. Naast de lijnscontroles wordende volgende algemene kwaliteitscontroles uitgevoerd:

- Blanco onderzoek.

- Terugvinding (recovery).

- $\quad$ Interne standaard voor borging opwerkmethode.

- Injectie standard.

- $\quad$ Gevoeligheid.

Bovenstaande controles staan beschreven in Wageningen Marine Research werkvoorschrift ISW 2.10.2.105.

Indien gewenst kunnen gegevens met betrekking tot de prestatiekenmerken van de analysemethoden bij het chemisch laboratorium worden opgevraagd.

Indien sprake is van onbeheerste kwaliteit worden passende maatregelen genomen. 


\section{Literatuur}

Barillé L., J. Prou, M. Heral, \& D. Razet, 1997. Effects of high natural seston concentrations on the feeding, selection, and absorption of the oyster Crassostrea gigas Thunberg. JE MBE 2012: $149-172$.

Berghahn R. \& M. Ruth, 2005. The disappearance of oysters from the Wadden Sea: a cautionary tale for no-take zones. Aquatic Conserv: Mar. Freshw. Ecosyst. 15: 91-104

Bouma, S. \& Lengkeek, W. (2013). Benthic communities on hard substrates within the first Dutch offshore wind farm (OWEZ). Nederlandse Faunistische Mededelingen, 41, pp.59-67.

Brown, J.H. 2016. Native oysters: special techniques for extra special product. The Grower April 2016: 14- 15.

Capelle, J. J. (2008) Restoration of the Oyster Ostrea edulis L. in the Wadden Sea. Wageningen IMARES, Rapport, 61 pagina's

Child, A.R. \& I. Laing, 1998. Comparative low temperature tolerance of small juvenile European, Ostrea edulis L., and Pacific oysters, Crassostrea gigas Thunberg. Aquaculture Research 29: 103113

Cronin, K., T. Van der Kaaij, J. Dijkstra, J. K. L. Van Beek, R. Plieger, \& M. Blaas, 2013. Setup and evaluation of baseline hydrodynamic and SPM models: MoS2-III: model-supported monitoring of SPM in the Southern North Sea. Deltares report 1208242, Deltares, Delft.

Davis, J.C., 1975. Minimal Dissolved Oxygen Requirements of Aquatic Life with Emphasis on Canadian Species: a Review. J. Fish. Board Can. 32: 2295-2332

Davis, H.C. \& A.D. Ansell, 1962. Survival and growth of larvae of the European oyster (Ostrea edulis L.) at lowered salinities. Biological Bulletin 122: 33-39.

Davis, H.C. \& A. Calabrese, 1969. Survival and growth of larvae of the European oyster (Ostrea edulis L.) at different temperatures. Biological Bulletin 136-193-199

Deltares, https://www.deltares.nl/nl/software/delft3d-suite/

Didderen, K. \& A. Gittenberger, 2013. Distribution and risk analysis of the American and Japanese oyster drill (Urosalpinx cinerea, Ocenebra inornata) update 2013. Bureau Waardenburg report 13-203, Culemborg.

Drinkwaard, A.C. 1961. Current velocity as an ecological factor in shell growth of Ostrea edulis. Shellfish Committee 47: 1-3.

Duineveld, G.C.A., Konitzer, A. \& R.P. Heyman, 1987. Amphiura filiformis (Ophiuridea: echinodermata) in the North Sea. Distribution, present and former abundance. Netherlands Journal of Sea Research. 21: 317-329.

Duren A. van, A. Gittenberger, A.C. Smaal, M. van Koningsveld, R. Osinga, J.A. Cado van der Lelij \& M.B. de Vries, 2016. Rijke riffen in de Noordzee Verkenning naar het stimuleren van natuurlijke riffen en gebruik van kunstmatig hard substraat. Deltares 2016.

Fuchs H.L., Elias J. Hunter, Erika L. Schmitt \& Regina A. Guazzo, 2013. Active downward propulsion by oyster larvae in turbulence. JEMBE 216: $1458-1469$

Gercken J. \& A. Schmidt 2014. Current Status of the European Oyster (Ostrea edulis) and Possibilities for Restoration in the German North Sea, 2014. BFN report.

Grant J., C.T. Enright \& A. Griswold, 1990. Resuspension and growth of Ostrea edulis: a field experiment. Marine Biology 104: 51-59.

Haure, J., C. Penisson, S. Bougrier, \& J.P Baud, 1998. Influence of temperature on clearance and oxygen consumption rates of the flat oyster Ostrea edulis: determination of allometric coefficients. Aquaculture 169: 211-224

Van der Have, T.M. \& Van der Zee, E., 2016. Terugkeer van de platte oester in de Waddenzee. Verkenning naar een mogelijk herstel van platte oesterbanken in de Waddenzee. Bureau Waardenburg en Altenburg \& Wymenga Rapportnr. 16-091, Culemborg i.o.v. Programma naar een Rijke Waddenzee.

Hayward, P. J., \& Ryland, J. S., 1998. Handbook of the Marine Fauna of North-West Europe. Oxford University Press, New York.

Helm, M.M., Bourne, N. \& Lovatelli, A., 2004. Hatchery culture of bivalves, a practical manual. FAO

Herman P., Beauchard O., \& van Duren L., 2014. De Staat van de Noordzee. Noordzeedagen 2015. 
Hoek, P.P.C. 1902. Rapport over de oorzaken van den achteruitgang in hoedanigheid van de Zeeuwsche oester. Ministerie van Waterstaat, Handel en Nijverheid, 's Gravenhage

Houziaux J-S., M. Fettweis, F. Francken, \& V. Van Lancker. 2011. Historic (1900) seafloor composition in the Belgian-Dutch part of the North Sea: A reconstruction based on calibrated visual sediment descriptions. Continental Shelf Research 31: 1043-1056

I cona, 1992. Noordzeeatlas voor het Nederlandse beleid en beheer. ICONA Den Haag / Stadsuitgeverij Amsterdam

Jordan-Cooley J.W., Romuald N. Lipcius, Leah B. Shaw, Jian Shen, \& J unping Shi, 2011. Bistability in a Differential Equation Model of Oyster Reef Height and Sediment Accumulation.

Kamermans P., E. Brummelhuis, J. Poelman, A. van Gool \& K. Troost, 2003. Onderzoek naar verbetering broedvangst oesters. RIVO trapport C003/04.

Kamermans, Pauline, Katrine Soma, Sander van den Burg, 2015. Haalbaarheid mosselteelt binnen offshorewindparken in de Nederlandse kustzone. Imares rapport C075/16

Keetels, G., V. Harezlak, T. Van Kessel, A. Van Rooijen, Y. Friocourt, T. Van der Kaaij, \& H. F. J. Los, 2012. Winning suppletiezand Noordzee 2013-2017; Validatierapport. 1204963-000-ZKS-0038, Deltares, Delft.

Laing, I.P., Walker, P. \& Areal, F., 2005. A feasibility study of native oyster (Ostrea edulis) stock generation in the United Kingdom. CARD Project FC1016 Native Oyster Stock Regeneration - a review of biological, technical and economic feasibility, CEFAS, $96 \mathrm{~S}$.

Lengkeek, W., Coolen, J., Gittenberger, A. \& Schrieken, N.,2013. Ecological relevance of shipwrecks in the North Sea. Nederlandse Faunistische Mededelingen, 41, 48-57

Lubet,, P., 1976. Ecophysiologie de la reproduction chez les mollusques lamellibranches. Haliotis, Paris 7: 49-55

Millican P.F. \& M.M. Helm, 1994. Effects of nutrition on larvae production in the European flat oyster, Ostrea edulis. Aquaculture 123: 83-94

Min. van Infrastructuur en Milieu \& Min. van Economische Zaken, 2016. Rijksstructuurvisie Windenergie op Zee Partiële herziening van het Nationaal Waterplan Hollandse Kust en Ten Noorden van de Waddeneilanden.

Montes, J, A. Villalba, M.C López, M.J Carballal, \& S.G. Mourelle, 1991. Bonamiasis in native flat oysters (Ostrea edulis L.) from two intertidal beds of the Ortigueira estuary (Galicia, N.W. Spain) with different histories of oyster culture. Aquaculture 93: 213-224

Newell, R.C., L.G. Johnson \& L.H. Kofoed, 1977. Adjustment of the components of energy balance in response to temperature change in Ostrea edulis. Oecologia 30: 97-110

Olsen, O.T., 1883. The Piscatorial Atlas of the North Sea and St. George's Channels. Taylor and Francis, London

Peirano, A., 2013. Wrecks on the Bottom: Useful, Ecological Sentinels? MARINE TECHNOLOGY SOCIETY JOURNAL 47: 118-127.

Pogoda B., B.H. Buck \& W. Hagen, 2011. Growth performance and conditions of oysters (Crassostrea gigas and Ostrea edulis) farmed in an offshore environment (North Sea Germany). Aquaculture 319: 484 - 492.

Sawusdee A., A.C. Jensen, K.J. Collins, \& C. Hauton, 2015. Improvements in the physiological performance of European flat oysters Ostrea edulis (Linnaeus, 1758) cultured on elevated reef structures: Implications for oyster restoration. Aquaculture 444: 41-48

Snelgrove P.V.R. \& C.A. Butman, 1994. Animal-sediment relationships revisited: cause versus effect. Oceanography and Marine Biology: an annual review 32: 111-177.

Sas H., P. Kamermans, T. van der Have, W. Lengkeek \& A. Smaal, 2016. Shellfish reef restoration pilots, Voordelta, The Netherlands. Annual report 2016.

Smaal, A.C., P. Kamermans, van der Have, M. Engelsma \& H.J.W. Sas, 2015. Feasibility of Flat Oyster (Ostrea edulis L.) restoration in the Dutch part of the North Sea, IMARES report C028/15.

Smyth, Dave, Louise Kregting, Björn Elsäßer, Richard Kennedy \& Dai Roberts, 2016. Using particle dispersal models to assist in the conservation and recovery of the overexploited native oyster (Ostrea edulis) in an enclosed sea lough. JSR 108: 50-59.

Vaquer-Sunyer, R. \& C. M. Duarte, 2008. Thresholds of hypoxia for marine biodiversity. PNAS 105: 15452-15457

Vera, M. Jens Carlsson, Jeanette EL Carlsson, Tom Cross, Sharon Lynch, Pauline Kamermans, Antonio Villalba, Sarah Culloty, \& Paulino Martinez, 2016. Current genetic status, temporal stability and structure of the remnant wild European flat oyster populations: conservation and restoring implications. Mar Biol $163-239$

Wasson, K, 2010. Informing Olympia Oyster Restoration: Evaluation of Factors That Limit Populations in a California Estuary. WETLANDS 30: 449-459. 
Woodin, S.A., 1991. Recruitment of infauna: positive or negative cues? American Zoologist 31: 797807.

Yildiz, Harun, Berber, Selcuk, \& Acarli, Sefa, 2011. Seasonal variation in the condition index, meat yield and biochemical composition of the flat oyster Ostrea edulis (Linnaeus, 1758) from the Dardanelles, Turkey. Italian journal of animal science Volume: 10 Issue: 1 Pages: 22-26 zu Ermgassen, P., Hancock, B., DeAngelis, B., Greene, J., Schuster, E., Spalding, M., \& Brumbaugh, R., 2016. Setting objectives for oyster habitat restoration using ecosystem services: A manager's guide. The Nature Conservancy, Arlington VA. 76pp 


\section{Verantwoording}

Rapport C035/17

Projectnummer: 4318100079

Dit rapport is met grote zorgvuldigheid tot stand gekomen. De wetenschappelijke kwaliteit is intern getoetst door een collega-onderzoekers en het betreffende MT lid van Wageningen Marine Research.

Akkoord:

Dr. Jeroen Wijsman

WMR onderzoeker

Handtekening:

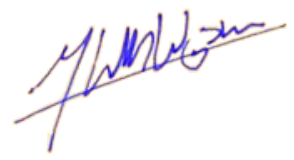

Datum:

19 mei 2017

Akkoord:

drs J. Asjes

MT lid

Handtekening:

Datum:

19 mei 2017 
Wageningen Marine Research

T: +31 (0)317480900

E: marine-research@wur.nl

www.wur.nl/marine-research

Visitors address

- Ankerpark 27, 1781 AG Den Helder

- Korringaweg 5, 4401 NT Yerseke

- Haringkade 1, 1976 CP IJ muiden
Wageningen Marine Research is the Netherlands research institute established to provide the scientific support that is essential for developing policies and innovation in respect of the marine environment, fishery activities, aquaculture and the maritime sector.

Wageningen University \& Research is specialised in the domain of healthy food and living environment.

\section{The Wageningen Marine Research vision:}

'To explore the potential of marine nature to improve the quality of life.'

\section{The Wageningen Marine Research mission}

- To conduct research with the aim of acquiring knowledge and offering advice on the sustainable management and use of marine and coastal areas.

- Wageningen Marine Research is an independent, leading scientific research institute.

Wageningen Marine Research is part of the international knowledge organisation Wageningen UR (University \& Research centre). Within Wageningen UR, nine specialised research institutes of Stichting Wageningen Research (a Foundation) have joined forces with Wageningen University to help answer the most important questions in the domain of healthy food and living environment. 